\title{
The influence of vegetation, fire spread and fire behaviour on biomass burning and trace gas emissions: results from a process-based model
}

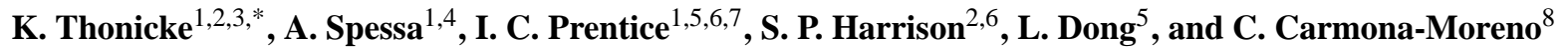 \\ ${ }^{1}$ formerly Max Planck Institute for Biogeochemistry, Hans-Knöll-Straße 10, Jena, 07701, Germany \\ ${ }^{2}$ School of Geographical Sciences, University of Bristol, University Road, Bristol, BS8 1SS, UK \\ ${ }^{3}$ Department of Biological Sciences, Macquarie University, North Ryde, NSW 2109, Australia \\ ${ }^{4}$ Grantham Institute for Climate Change, and Division of Biology, Imperial College, Silwood Park Campus, \\ Ascot, SL5 7PY, UK \\ ${ }^{5}$ Potsdam Institute for Climate Impact Research (PIK) e.V., Telegraphenberg A31, Potsdam, 14473, Germany \\ ${ }^{6}$ National Centre for Atmospheric Sciences (NCAS), NCAS-Climate, University of Reading, Earley Gate, \\ Reading, RG6 6BB, UK \\ ${ }^{7}$ QUEST, Department of Earth Sciences, University of Bristol, Wills Memorial Building, Queen's Road, Bristol, BS8 1RJ, UK \\ ${ }^{8}$ Global Vegetation Monitoring Unit, Joint Research Centre Ispra, Ispra, Italy \\ *now at: Potsdam Institute for Climate Impact Research (PIK) e.V., Telegraphenberg A31, Potsdam, 14473, Germany
}

Received: 16 December 2009 - Published in Biogeosciences Discuss.: 27 January 2010

Revised: 27 May 2010 - Accepted: 2 June 2010 - Published: 23 June 2010

\begin{abstract}
A process-based fire regime model (SPITFIRE) has been developed, coupled with ecosystem dynamics in the LPJ Dynamic Global Vegetation Model, and used to explore fire regimes and the current impact of fire on the terrestrial carbon cycle and associated emissions of trace atmospheric constituents. The model estimates an average release of $2.24 \mathrm{Pg} \mathrm{Cyr}^{-1}$ as $\mathrm{CO}_{2}$ from biomass burning during the 1980s and 1990s. Comparison with observed active fire counts shows that the model reproduces where fire occurs and can mimic broad geographic patterns in the peak fire season, although the predicted peak is 1-2 months late in some regions. Modelled fire season length is generally overestimated by about one month, but shows a realistic pattern of differences among biomes. Comparisons with remotely sensed burnt-area products indicate that the model
\end{abstract}

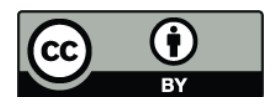

Correspondence to: $\mathrm{K}$. Thonicke (kirsten.thonicke@pik-potsdam.de) reproduces broad geographic patterns of annual fractional burnt area over most regions, including the boreal forest, although interannual variability in the boreal zone is underestimated.

\section{Introduction}

Fire has a profound impact on vegetation dynamics by initiating succession, selecting plants adapted to the fire regime in fire-dominated ecosystems, and influencing vegetation productivity and thus litter and fuel load (Bergeron et al., 2004; Pyne et al., 1996; Cochrane, 2003; Whelan, 1995; Goldammer and Furyaev, 1996). The conditions for fire are determined by climate and the state of the vegetation. Changes in fuel load in semi-arid, savanna and Mediterranean ecosystems caused by seasonal or interannual rainfall variability can limit or promote fire spread (e.g. Randerson et al., 2005; Stephens and Moghaddas, 2005; Mermoz et al.,

Published by Copernicus Publications on behalf of the European Geosciences Union. 


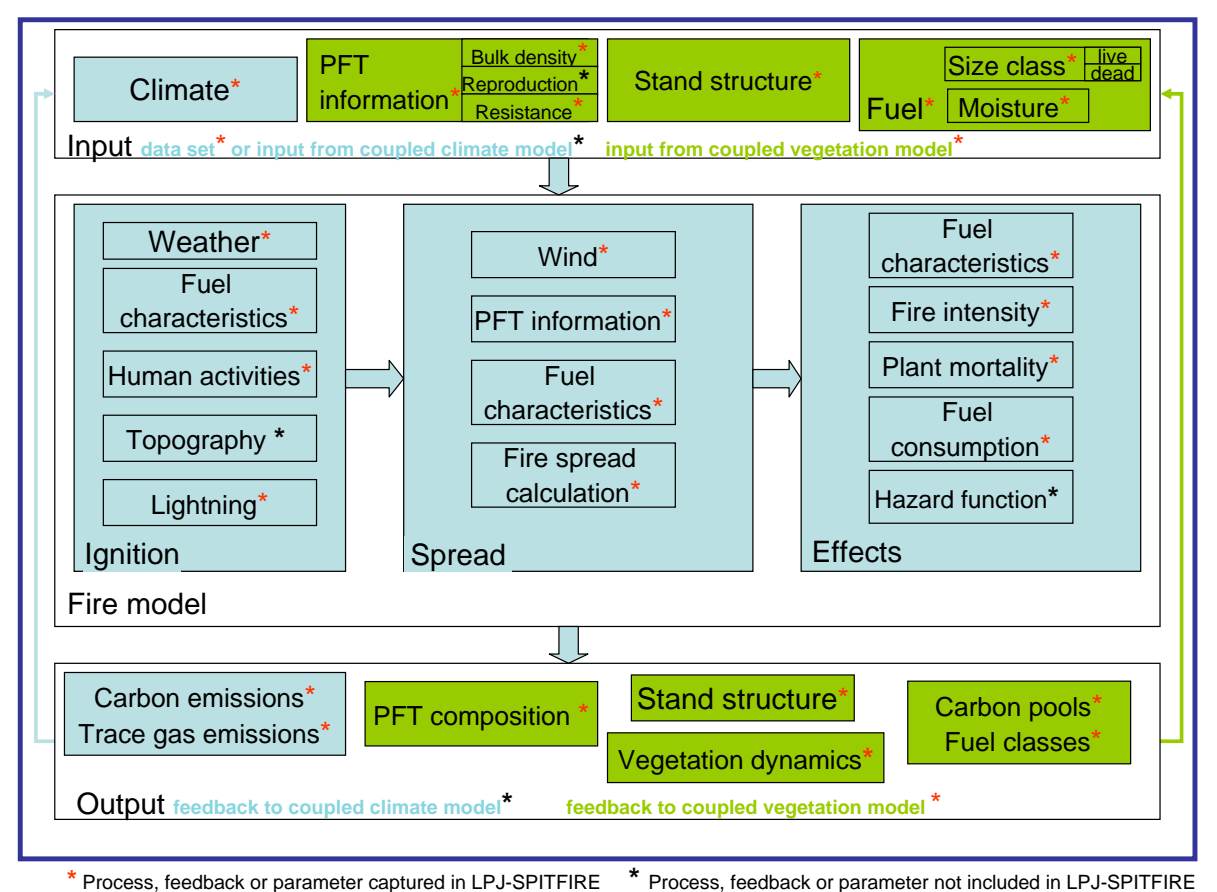

Fig. 1. Scheme describing model features a process-based fire model for dynamic vegetation models or climate-vegetation models should consider (following Fosberg et al., 1999; Keane et al., 2004; Pausas et al., 2004).

2005), whereas temperature is the main limiting factor on the length of the fire season in boreal and temperate ecosystems where sufficient fuel is available for burning (Schimmel and Granström, 1997). The annual area burnt in boreal regions can vary by an order of magnitude or more as a result of interannual variation in temperature (French et al., 2002; Sukhinin et al., 2004; Conard et al., 2002; Girardin et al., 2004; Flannigan et al., 2005), while variations in annual area burnt in the tropics are tied to variations in precipitation linked to the El Niño-Southern Oscillation (Allan and Southgate, 2002; Randerson et al., 2005; Harris et al., 2008).

Emissions from biomass burning contribute substantially to the global budgets of trace gases and aerosols that affect climate. Biomass burning is thought to contribute up to $50 \%$ of global $\mathrm{CO}$ and $\mathrm{NO}_{\mathrm{x}}$ emissions in the troposphere (Galanter et al., 2000), and a significant part of the observed increases in atmospheric growth rates of $\mathrm{CO}, \mathrm{CO}_{2}$ and $\mathrm{CH}_{4}$ during large El Niño events (van der Werf et al., 2004). Where fire forms an integral part of the ecosystem, as is the case e.g. in the boreal zone, tropical savannas and Mediterranean-type ecosystems, the $\mathrm{CO}_{2}$ emissions are assimilated by re-growing vegetation which has evolved adaptation strategies to limit fire damage and/or allow effective regeneration. If the fire regimes of these ecosystems remained unchanged, they would not be net contributors to increasing atmospheric $\mathrm{CO}_{2}$ concentrations. Estimates of the total carbon released annually from fires range from about 1.7 to 2.5 PgC (Ito and Penner, 2004; Andreae and Merlet, 2001;
Seiler and Crutzen, 1980; van der Werf et al., 2004). These estimates are based on inventories, satellite-based fire products and simple emission models. Their range is due to uncertainties in the estimates of global area burnt, fuel load and completeness of combustion (e.g. Hoelzemann et al., 2004; Kasischke et al., 2005; Schultz et al., 2008). Reliance on observational fire data precludes their extrapolation to future scenarios.

A prognostic fire regime model embedded in a dynamic global vegetation model (DGVM) could in principle simulate the effects of changes in climate on fire regimes and emissions through the interaction between fire and vegetation dynamics, with climate influencing both elements. Such a model should consider the influence of fuel characteristics, weather and ignition sources for simulating fire ignition; simulate fire spread explicitly; and include fire intensity, fuel characteristics and fuel consumption to compute fire effects and resulting pyrogenic emissions (Fosberg et al., 1999; Keane et al., 2004; Pausas et al., 2004). A processbased global fire model should use input from a climate data set or coupled climate model and/or information about PFTs, fuel characteristics and stand structure being provided by a DGVM (see Fig. 1). Fosberg et al. (1999) suggested the use of hazard functions to describe the effects on fire regimes and affected vegetation, but this concept was not developed further in landscape fire models (Keane et al., 2004). Instead, functions describing plant mortality arising from fuel consumption, and the damage of plants as a result of fire, were 


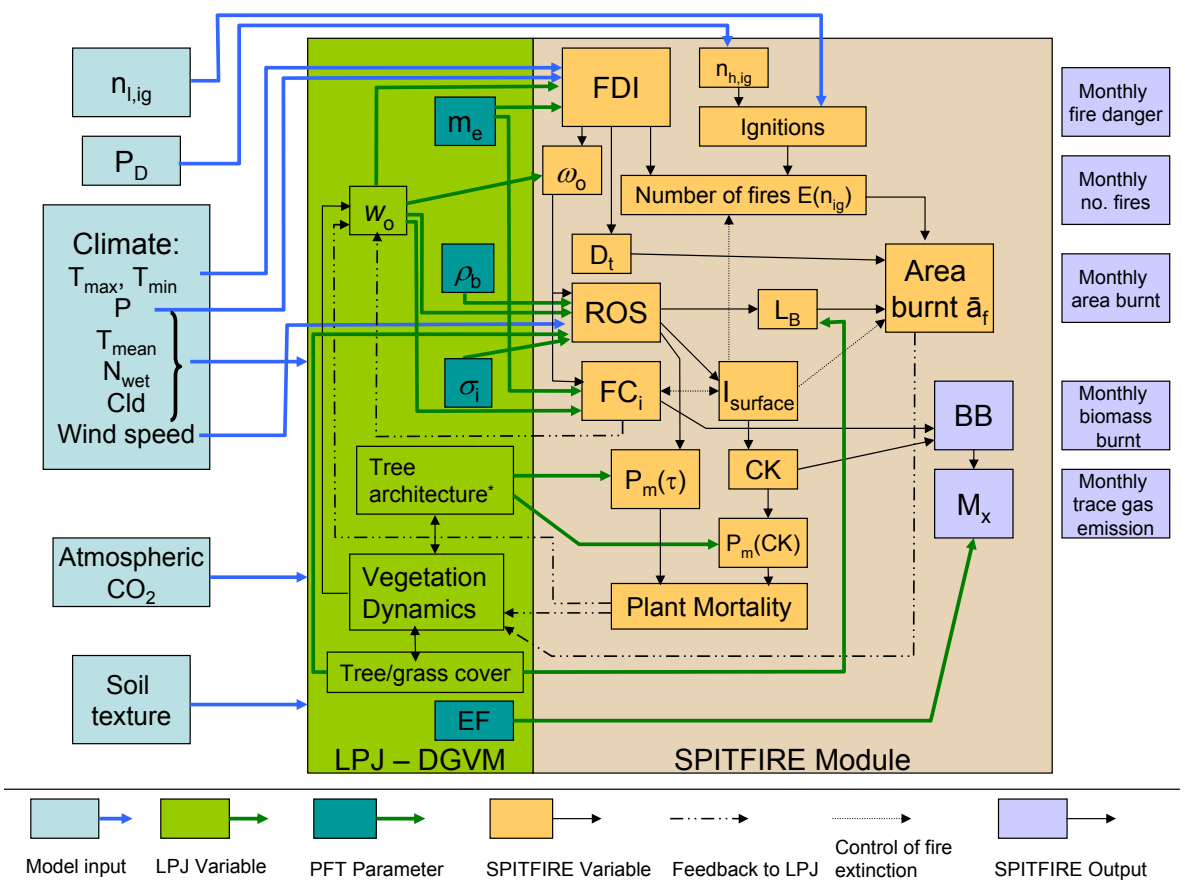

Fig. 2. Systems diagram describing input to LPJ-SPITFIRE, interaction between LPJ and the SPITFIRE module and potential SPITFIRE output variables. Only those LPJ processes, variables or parameter are listed that drive SPITFIRE variables or are influenced by SPITFIRE. Naming of variables follows notation used in the equations in the Methods section, others: $P$ - precipitation, $N_{\text {wet }}-$ number of wet days, Cld-cloudiness; * includes PFT-Parameter $C L, F$, parl and par2, $r(C K)$. SPITFIRE output variables other than listed or for a different time period (daily, annually) can be created as well, this is user dependent.

developed. Fosberg et al. (1999) also noted the importance of simulating emissions of $\mathrm{CO}_{2}$ and other trace atmospheric constituents for the assessment of the feedback loop involving fire, vegetation and climate (Fig. 1). Keane et al. (2004) and Fosberg et al. (1999) also referred to the need to model vegetation dynamics. The fire traits that a vegetation model should describe included reproduction (vegetative or seedbased), the ability to resprout, fire resistance, and fuel characteristics such as bulk density and size distribution (Fosberg et al., 1999; Keane et al., 2004; Pausas et al., 2004).

There have been previous attempts to simulate fire within a DGVM framework (Thonicke et al., 2001; Lenihan and Neilson, 1998; Venevsky et al., 2002). However, the existing "fire-enabled" DGVMs have considerable limitations. GlobFIRM (Thonicke et al., 2001), for example, derives fractional area burnt in a grid cell from the simulated length of fire season and minimal fuel load annually, but does not specify ignition sources and assumes a constant fire-induced mortality rate for each plant functional type (PFT). Reg-FIRM (Venevsky et al., 2002), an alternative fire model in LPJ, treats climatic fire danger, wildfire ignitions and fire spread as distinct processes, but fire effects on vegetation mortality are prescribed parameters as in Glob-FIRM, and trace gas and aerosol emissions are unquantified. MC-FIRE, embedded in the MC1 DGVM (Bachelet et al., 2000; Lenihan and
Neilson, 1998), explicitly simulates fire spread (following Cohen and Deeming, 1985) and fire effects including postfire mortality (following Peterson and Ryan, 1986), but allows only one ignition per year per grid cell, and requires a drought index and information on time since last fire to estimate the fraction of the grid cell burnt (Lenihan and Neilson, 1998). Arora and Boer (2005) present a simulation model of fire activity and emissions from biomass burning within the Canadian Terrestrial Ecosystem Model (CTEM; Verseghy et al., 1993). CTEM-fire simulates the feedback between vegetation and fires, but adopts a simplified parameterised approach. It models fire rate of spread as a function of wind speed and soil moisture but does not consider the influence of litter load and moisture content explicitly. Fire-induced consumption of biomass and plant mortality are prescribed, and do not vary with fire intensity.

Here we present a new process-based fire regime model, SPITFIRE (SPread and InTensity of FIRE), fully coupled into the LPJ DGVM (Sitch et al, 2003) with the improved treatment of hydrological processes described by Gerten et al. (2004). It includes explicit representation of ignitions and of the physical properties and processes determining fire spread and intensity (Fig. 2). The model distinguishes the controls on the drying of different litter size classes from those on soil moisture and live fuel moisture, allowing the 
separation of processes with different time scales of response to atmospheric conditions. It also adopts a process-based formulation of the effects of fire on vegetation as a function of structural plant properties.

Until recently, the development of fire-enabled DGVMs has been hampered by the lack of well-validated global fire products. Thus, pre-existing models have not been systematically evaluated against observations at a global scale. Here, we have developed and applied stronger model benchmarking procedures for global coupled fire-vegetation modelling. This procedure includes evaluating the performance of the model using the MODIS Active Fire Count (Giglio et al., 2006) and Global Burnt Surface (GBS; Carmona-Moreno et al., 2005) products. Results are also compared to independent estimates of global biomass burning.

\section{Methods}

\subsection{Modelling principles}

SPITFIRE explicitly considers ignition rates, and distinguishes lightning- and human-caused "ignition events". Ignition events produce fires only when fuel is present and fuel conditions are sufficiently dry. Daily precipitation is simulated using the weather generator in LPJ, based on monthly precipitation and wet days (Gerten et al., 2004). This is the only stochastic process in the combined LPJ-SPITFIRE model. Where SPITFIRE uses parameters from other statistical modelling studies, its mean is applied instead of varying them stochastically.

SPITFIRE simulates fire spread as a two-step process. First, the model assesses whether there is enough fuel and whether the fuel complex is dry enough to ignite. Second, if these conditions are satisfied, then fire spreads as a function of several factors, including wind-speed. Fire rate of spread (ROS) calculations follow Rothermel's equations (Rothermel, 1972; Pyne et al., 1996; Wilson, 1982). The Rothermel model was chosen because it has been applied across a wide range of biomes, from boreal to tropical; as part of the United States Department of Agriculture (USDA) system for the evaluation of operational fire hazard (Pyne et al., 1996). Further, while fuel load is static in the USDA system, LPJ simulates fuel load dynamically thus representing an advance over standard applications of the Rothermel model.

Our implementation of the Rothermel model takes into account the moisture content of different dead fuel size classes, which are calculated as function of ambient weather conditions as quantified by the Nesterov index (Nesterov, 1949). This simple index accumulates a weather-dependent measure of drying power over periods of consecutive days without precipitation. Dead fuel moisture plays a key role in the model, as a control over fire danger, ROS (Appendix A), and completeness of combustion (Appendix B).
Several fire danger indices are in use, including the Canadian Fire Weather Index (CFFBG, 1992) which has also been adapted to Indonesia .(De Groot et al., 2007), the South African Lowveld model (S. Archibald, personal communication, 2010), the MacArthur Grassland Fire Danger Rating and the MacArthur Forest Fire Danger Index (Bradstock et al., 2002). These indices, developed for operational purposes, aim to integrate all factors influencing fire (including factors controlling ROS). SPITFIRE also takes this complexity into account, but rather than summarising it in a single index, it simulates fire as a series of linked process-based steps.

Surface fire intensity is explicitly simulated in SPITFIRE. Ignition events that generate an insufficiently intense fire do not lead to spreading fires (see dotted line in Fig. 2). The model also calculates whether a surface fire has sufficient height to scorch the tree crown following van Wagner (1977). The risks of fire-damaged trees dying from either crown scorch (Dickinson and Johnson, 2001; Johnson, 1992) or cambial death (e.g. Rigolot, 2004; Stephens and Finney, 2002), the two most important causes of post-fire mortality, are calculated. Thus, modelled fire behaviour influences the amount of biomass burning, and determines the generation of fuel for the following fire season through post-fire mortality. Fire-related emissions of $\mathrm{CO}_{2}$, other trace gases - $\mathrm{CO}, \mathrm{CH}_{4}$, volatile organic compounds (VOC) and $\mathrm{NO}_{\mathrm{x}}-$ and total particulate matter (TPM) are derived using emission factors from Andreae and Merlet (2001) and Andreae (personal communication, 2003) Post-fire conditions determine vegetation regeneration, which in turn affects the potential for future fires through new fuel development and flammability. Although human-caused ignitions are taken into account, there is no attempt to simulate other aspects of human management of fire, such as active fuel management or firefighting.

SPITFIRE derives information about vegetation composition, and fuel amount and characteristics, from the LPJ DGVM (Fig. 2). LPJ simulates vegetation dynamics in terms of the growth of and competition among nine PFTs; it has been extensively evaluated and performs well in terms of land-atmosphere exchanges of $\mathrm{CO}_{2}$ (McGuire et al., 2001; Peylin et al., 2005; Sitch et al., 2003), water fluxes (Gerten et al., 2004, 2005) and global vegetation distribution (Cramer et al., 2001; Sitch et al., 2003).

The state description of a grid cell in LPJ includes information on properties such as the stem diameter and height of the "average individual" of woody PFTs, which SPITFIRE uses to calculate the effects of fire in terms of mortality rates and combustion of living biomass. The carbon pools that represent the above-ground biomass of each PFT are allocated among four fuel classes: 1 -h (leaves and twigs, i.e. leaf mass plus $4.5 \%$ of the carbon stored as heartwood (HW) and sapwood (SW), respectively), 10-h (small branches, i.e. 7.5\% of HW and SW), 100-h (large branches, i.e. $21 \%$ of HW and SW) and 1000-h (boles or trunks, i.e. $67 \%$ of HW and $\mathrm{SW})$. The designation of these fuel classes in terms of hours 
Table 1. PFT-specific model parameter values. TrBE: Tropical broadleaved evergreen, TrBR: Tropical broadleaved raingreen, TNE: Temperate needle-leaved evergreen, TBE: Temperate broadleaved evergreen, TBS: Temperate broadleaved summergreen, BNE: Boreal needleleaved evergreen, BS: Boreal summergreen, $\mathrm{C} 3 \mathrm{G}$ : $\mathrm{C}_{3}$ grass/herbaceous, $\mathrm{C} 4 \mathrm{G}: \mathrm{C}_{4}$ grass/herbaceous. Crown damage parameters $R(C K)$ and $p$ are taken from Peterson and Ryan (1986), Cochrane (2003) and Williams (1998).

\begin{tabular}{|c|c|c|c|c|c|c|c|c|c|c|c|c|c|c|c|c|}
\hline & \multicolumn{2}{|c|}{$\begin{array}{l}\text { Fuel bulk density } \\
\qquad\left[\mathrm{kg} \mathrm{m}^{-3}\right]\end{array}$} & \multicolumn{2}{|c|}{$\begin{array}{l}\text { Scorch height } \\
\text { parameter }\end{array}$} & \multirow{2}{*}{$\begin{array}{l}\text { Crown } \\
\text { length } \\
\text { parameter }\end{array}$} & \multicolumn{3}{|c|}{ Bark thickness parameters } & \multicolumn{3}{|c|}{$\begin{array}{l}\text { Crown damage } \\
\text { parameters }\end{array}$} & \multicolumn{4}{|c|}{ Emission factors } & \multirow[b]{2}{*}{$\mathrm{NO}_{\mathrm{x}}$} \\
\hline PFT & $\rho_{b}$ & Reference & $F$ & Reference & & par1 & par2 & Reference & $R(C K)$ & $p$ & $\mathrm{CO}_{2}$ & $\mathrm{CO}$ & $\mathrm{CH}_{4}$ & VOC & TPM & \\
\hline $\operatorname{TrBE}$ & 25 & none & 0.1487 & $\begin{array}{l}\text { (Cochrane, } \\
\text { 2003) }\end{array}$ & $1 / 3$ & 0.0301 & 0.0281 & $\begin{array}{l}\text { (Cochrane, } \\
\text { 2003; Uhl and } \\
\text { Kauffman, } \\
\text { 1990) }\end{array}$ & 1 & 3 & 1580 & 103 & 6.8 & 8.1 & 8.5 & 1.85 \\
\hline TrBR & 25 & none & 0.061 & $\begin{array}{l}\text { (Williams } \\
\text { et al., 1998) }\end{array}$ & $1 / 10$ & 0.1085 & 0.212 & $\begin{array}{l}\text { (Hoffmann et } \\
\text { al., 2003) }\end{array}$ & 0.05 & 3 & 1664 & 63 & 2.2 & 3.4 & 8.5 & 2.35 \\
\hline TNE & 25 & $\begin{array}{l}\text { (Brown, } \\
\text { 1981; Keane } \\
\text { et al., 1990; } \\
\text { Merida, } \\
\text { 1999; Miller } \\
\text { and Urban, } \\
\text { 1999) }\end{array}$ & 0.1 & $\begin{array}{l}\text { (Williams } \\
\text { et al., 1998) }\end{array}$ & $1 / 3$ & 0.0367 & 0.0592 & $\begin{array}{l}\text { (Reinhardt et } \\
\text { al., 1997) }\end{array}$ & 1 & 3.75 & 1568 & 106 & 4.8 & 5.7 & 17.6 & 3.0 \\
\hline TBE & 10 & $\begin{array}{l}\text { (Merida, } \\
\text { 1999) }\end{array}$ & 0.371 & $\begin{array}{l}\text { (Van } \\
\text { Wagner, } \\
1977 \text { ) }\end{array}$ & $1 / 3$ & 0.0451 & 0.1412 & $\begin{array}{l}\text { (Reinhardt et } \\
\text { al., 1997) }\end{array}$ & 0.95 & 3 & 1568 & 106 & 4.8 & 5.7 & 17.6 & 3.0 \\
\hline TBS & 22 & $\begin{array}{l}\text { (Keane et al., } \\
\text { 1990; Hély } \\
\text { et al., 2000) }\end{array}$ & 0.094 & $\begin{array}{l}\text { (Dickinson } \\
\text { and } \\
\text { Johnson, } \\
\text { 2001) }\end{array}$ & $1 / 3$ & 0.0347 & 0.1086 & $\begin{array}{l}\text { (Reinhardt et } \\
\text { al., 1997) }\end{array}$ & 1 & 3 & 1568 & 106 & 4.8 & 5.7 & 17.6 & 3.0 \\
\hline BNE & 25 & $\begin{array}{l}\text { (Hély et al., } \\
\text { 2000; Miller } \\
\text { and Urban, } \\
\text { 1999) }\end{array}$ & 0.11 & $\begin{array}{l}\text { (Hély et al., } \\
\text { 2003) }\end{array}$ & $1 / 3$ & 0.0292 & 0.2632 & $\begin{array}{l}\text { (Reinhardt et } \\
\text { al., 1997) }\end{array}$ & 1 & 3 & 1568 & 106 & 4.8 & 5.7 & 17.6 & 3.0 \\
\hline BS & 22 & $\begin{array}{l}\text { (Keane et al., } \\
\text { 1990) }\end{array}$ & 0.094 & $\begin{array}{l}\text { (Dickinson } \\
\text { and } \\
\text { Johnson, } \\
2001 \text { ) }\end{array}$ & $1 / 3$ & 0.0347 & 0.1086 & $\begin{array}{l}\text { (Reinhardt et } \\
\text { al., 1997) }\end{array}$ & 1 & 3 & 1568 & 106 & 4.8 & 5.7 & 17.6 & 3.0 \\
\hline C3G & 2 & $\begin{array}{l}\text { (Miller and } \\
\text { Urban, 1999; } \\
\text { Merida, 1999) }\end{array}$ & n.a. & n.a. & n.a. & n.a. & n.a. & n.a. & n.a. & n.a. & 1568 & 106 & 4.8 & 5.7 & 17.6 & 3.0 \\
\hline $\mathrm{C} 4 \mathrm{G}$ & 2 & $\begin{array}{l}\text { (Miller and } \\
\text { Urban, 1999; } \\
\text { Merida, 1999) }\end{array}$ & n.a. & n.a. & n.a. & n.a. & n.a. & n.a. & n.a. & n.a. & 1664 & 63 & 2.2 & 3.4 & 8.5 & 2.35 \\
\hline
\end{tabular}

describes the order of magnitude of time required for fuel to lose (or gain) $63 \%$ of the difference between its current moisture content and the equilibrium moisture content under defined atmospheric conditions. The larger the fuel elements, the smaller their surface-to-area volume ratio, and the longer they take to reach an equilibrium moisture content (Albini, 1976; Anderson, 1982). Above-ground biomass becomes dead fuel when it is transferred to detritus by turnover or mortality. The 1-h fuel class also includes live leaf biomass of herbaceous PFTs. Only the 1-h, 10-h and 100-h fuel classes influence fire spread (Rothermel, 1972; Wilson, 1982; Pyne et al., 1996). The fraction of the fuel consumed by fire is a function of the fuel moisture content and also varies among the fuel classes (Peterson and Ryan, 1986). Vegetation composition in terms of PFTs thus influences fire behaviour in multiple ways, through the ratios of different fuel classes and their properties, while fire behaviour influences the PFT composition through the PFT's different abilities and methods to resist and survive after fire.

A number of parameters used for fire modelling are PFTspecific and must be specified for fire modelling. Parameters that differ among PFTs are fuel bulk density (FBD) and quantities that influence scorch height, crown length, bark thickness, and propensity for crown damage (Table 1). Typical parameter values were obtained from the literature.

\subsection{Basic equations}

The area burnt in a grid cell in a day, $A_{\mathrm{b}}\left(\mathrm{ha} \mathrm{d}^{-1}\right)$, is the product of the probability of fire per unit time at any point 
within the grid cell $P_{\mathrm{b}}\left[\mathrm{d}^{-1}\right]$ and the grid cell area $A($ ha):

$A_{\mathrm{b}}=P_{\mathrm{b}} \cdot A$.

$P_{\mathrm{b}}$ is the product of the expected number of fires per unit area and time, $E\left(n_{\mathrm{f}}\right)\left(\mathrm{ha}^{-1} \mathrm{~d}^{-1}\right)$, and the mean fire area $\bar{a}_{\mathrm{f}}(\mathrm{ha})$. $E\left(n_{\mathrm{f}}\right)$ in turn is the product of the expected number of "ignition events" (i.e. events such as lightning strikes which could start a fire, given suitable conditions) per unit area and time, $E\left(n_{\mathrm{ig}}\right)\left(\mathrm{ha}^{-1} \mathrm{~d}^{-1}\right)$, and the fire danger index $(F D I)$, which we define here in a narrow sense, as the probability that an ignition event will start a fire (regardless of how large the fire becomes once started). Thus, Eq. (1) can be rewritten as

$A_{\mathrm{b}}=E\left(n_{\mathrm{ig}}\right) \cdot F D I \cdot \bar{a}_{\mathrm{f}} \cdot A$.

We equate $E\left(n_{\mathrm{ig}}\right)$ with the sum of independent estimates of the numbers of lightning $\left(n_{1, \text { ig }}\right)$ and human-caused $\left(n_{\mathrm{h}, \mathrm{ig}}\right)$ ignition events, disregarding stochastic variations.

\subsubsection{Ignition events}

The frequency of lightning-caused ignition events $\left(n_{1, \mathrm{ig}}\right)$ $\left(\mathrm{ha}^{-1} \mathrm{~d}^{-1}\right)$ is prescribed from the LIS/OTD $0.5^{\circ} \mathrm{HRFC}$ data set (LIS/OTD 0.5 Degree HRFC; Christian et al., 2003), which gives the monthly frequency of total lightning flashes averaged over five years of data. The data were interpolated between months to yield a quasi-daily climatology of flashes. Latham and Williams (2001) indicated that 0.20 of these are cloud-to-ground flashes (CG) and that their efficiency in starting fires, under favourable conditions for burning, is 0.04 (Latham and Williams, 2001; Latham and Schlieter, 1989). We use these factors to convert daily flashes to ignition events, although slightly modified values to account for CG flashes and energy efficiency could also be applied, however the model sensitivity of CG to the overall model outcome is expected to be small. Interannual variability in lightning is generally small in comparison to the seasonal variations, and is neglected in this study.

The number of human-caused ignition events $\left(n_{h, i g}\right)$ $\left(\mathrm{ha}^{-1} \mathrm{~d}^{-1}\right.$ ) is modelled as a non-linear function of population density, assuming that this number initially increases as more people settle within a previously unoccupied region (e.g. Cochrane et al., 1999) but declines with further increases in population density due to landscape fragmentation, urbanisation and associated infrastructural changes. The function is

$n_{\mathrm{h}, \mathrm{ig}}=P_{\mathrm{D}} \cdot k\left(P_{\mathrm{D}}\right) \cdot a\left(N_{\mathrm{D}}\right) / 100$,

where

$k\left(P_{\mathrm{D}}\right)=30.0 \cdot e^{-0.5 \cdot \sqrt{P_{\mathrm{D}}}}$,

$P_{\mathrm{D}}$ is the population density (individuals $\left.\mathrm{km}^{-2}\right)$, and $a\left(N_{\mathrm{D}}\right)$ (ignitions individual ${ }^{-1} \mathrm{~d}^{-1}$ ) is a parameter expressing the propensity of people to produce ignition events. Equation (3) has a maximum at a population density of $16 \mathrm{~km}^{-2}$. The form of the function is supported e.g. by the analysis of Archibald et al. (2009), who showed that numbers of fires in southern Africa tend to increase with increasing population density up to about $10 \mathrm{~km}^{-2}$, declining thereafter. The function approaches zero at high population density. Estimates of the constant $a\left(N_{\mathrm{D}}\right)$ were obtained by an inverse method, using data on numbers of human-caused fires and population densities for various regions (see Sect. 2.3).

\subsubsection{Fuel moisture content}

The Nesterov Index $\operatorname{NI}(d)\left({ }^{\circ} \mathrm{C}^{2}\right)$ is a cumulative function of daily maximum temperature $T_{\max }(d)$ and dew-point temperature $T_{\mathrm{dew}}(d)\left({ }^{\circ} \mathrm{C}\right)$ :

$N I(d)=\sum T_{\max }(d) \cdot\left(T_{\max }(d)-T_{\mathrm{dew}}(d)\right)$,

where summation is over the period of consecutive days (up to and including the current day) with precipitation $\leq 3 \mathrm{~mm}$. We approximate $T_{\mathrm{dew}}(d)$ by $\left(T_{\min }(d)-4\right)$, where $T_{\min }(d)$ is the daily minimum temperature (Running et al., 1987), the same approach used by Venevsky et al. (2002). A weightedaverage estimate $\omega_{o}$ of the relative moisture content of the 1-h, 10-h and 100-h fuels is calculated daily as:

$\omega_{o}=e^{\left(-\left(\sum_{i=1}^{3} \alpha_{i} \cdot \frac{w_{\mathrm{o}_{\mathrm{i}}}}{w_{\mathrm{o}}}\right) \cdot N I\right)}$,

where $w_{\mathrm{o}_{\mathrm{i}}}$ are the quantities of the three fuel classes $\left(\mathrm{g} \mathrm{C} \mathrm{m}^{-2}\right)$ and $w_{\mathrm{o}}$ is their total. The values of $\alpha_{i}\left({ }^{\circ} \mathrm{C}^{-2}\right)$ applied to the three fuel classes are in inverse proportion to their surface-area-to-volume ratios, with $\alpha_{1 \mathrm{~h}}=1.010^{-3}$, $\alpha_{10 \mathrm{~h}}=5.4210^{-5}$ and $\alpha_{100 \mathrm{~h}}=1.4910^{-5}$. The moisture content of the 1-h fuel class is modified (see Appendix B) by the inclusion of live fuel (herbaceous leaf biomass) whose moisture content depends on the moisture content of the top soil layer.

\subsubsection{Fire danger}

The probability that an ignition event becomes a spreading fire depends on the current litter moisture $\omega_{o}$ and the probability of fire spread $P_{\text {spread }}$, which depends on fire weather conditions as expressed by NI. $P_{\text {spread }}$ decreases linearly as litter moisture $\omega_{o}$ increases towards its moisture of extinction $m_{\mathrm{e}}$ :

$P_{\text {spread }}=\left\{\begin{array}{l}1-\frac{\omega_{o}}{m_{\mathrm{e}}}, \omega_{o} \leq m_{\mathrm{e}} \\ 0, \omega_{o}>m_{\mathrm{e}}\end{array}\right\}$.

Fire danger is defined as zero in the absence of fuel or for wet fuel, and unity for completely dry fuel. Thus, combining Eqs. (6) and (7) we obtain:

$F D I=\max \left(0,\left(1-\frac{1}{m_{\mathrm{e}}} e^{-\left(\sum_{i=1}^{3} \alpha_{i} \cdot \frac{w_{0_{\mathrm{i}}}}{w_{\mathrm{o}}}\right) \cdot N I}\right)\right)$

when fuel is present. When fuel is absent the right-hand term has no physical meaning and $F D I$ is set to zero. 


\subsubsection{Rate of spread}

The rate of spread of a typical fire in a given day and grid cell is obtained using Rothermel's equations (Rothermel, 1972; Pyne et al., 1996; Wilson, 1982). These equations are based on a combination of physical principles and experimental measurements. They are extensively used in operational fire management to predict fire behaviour as a function of weather and fuel conditions. The empirical fuel models used operationally to characterize the physical properties of the fuel bed in different ecosystem types are replaced in the model by information derived from LPJ about the amounts of different fuel classes for each PFT present.

The forward rate of spread $R O S_{\mathrm{f}, \text { surface }}\left(\mathrm{m} \mathrm{min}^{-1}\right)$ is given by:

$\operatorname{ROS}_{\mathrm{f}, \text { surface }}=\frac{I_{\mathrm{R}} \cdot \xi \cdot\left(1+\Phi_{w}\right)}{\rho_{b} \cdot \varepsilon \cdot Q_{\mathrm{ig}}}$.

where $I_{R}$ is the reaction intensity, i.e. the energy release rate per unit area of fire front $\left(\mathrm{kJ} \mathrm{m}^{-2} \mathrm{~min}^{-1}\right)$; $\xi$ is the propagating flux ratio, i.e. the proportion of $I_{R}$ that heats adjacent fuel particles to ignition; $\Phi_{w}$ is a multiplier that accounts for the effect of wind in increasing the effective value of $\xi ; \rho_{b}$ is the fuel bulk density $\left(\mathrm{kg} \mathrm{m}^{-3}\right)$, assigned by PFT (Table 1) and weighted over the 1-, 10- and 100-h dead fuel classes; $\varepsilon$ is the effective heating number, i.e. the proportion of a fuel particle that is heated to ignition temperature at the time flaming combustion starts; and $Q_{\mathrm{ig}}$ is the heat of pre-ignition, i.e. the amount of heat required to ignite a given mass of fuel $\left(\mathrm{kJ} \mathrm{kg}^{-1}\right)$. With fuel bulk density $\rho_{b}$ defined as a PFT parameter, surface-area-to-volume ratios change with fuel load. This approach was taken because LPJ quantifies the amount of fuel but not its packing ratio. The ROS equations are further described in Appendix A.

The forward wind speed $U_{\text {forward }}$ as used in Eq. (A5) (see Appendix A) is reduced by a factor ranging from 0.4 for woody to 0.6 for herbaceous PFTs (as an average weighted by their respective foliar projective covers). The backward rate of spread $R O S_{\mathrm{b}, \text { surface }}$ is given by:

$R O S_{\mathrm{b}, \text { surface }}=R O S_{\mathrm{f}, \text { surface }} \cdot e^{-0.012 \cdot U_{\text {forward }}}$

(CFFBG, 1992). Assuming fires develop an elliptical shape, because of the different velocities at which they spread with and against prevailing winds (Albini, 1976; Johnson, 1992; CFFBG, 1992), the mean fire area is:

$\bar{a}_{\mathrm{f}}=\frac{\frac{\pi}{4 \cdot L_{\mathrm{B}}} \cdot D_{\mathrm{T}}^{2}}{10000}$,

where $L_{\mathrm{B}}$ is the length-to-breadth ratio of the ellipse (CFFBG, 1992), estimated as a weighted average of

$L_{\mathrm{B}, \text { tree }}=1.0+8.729 \cdot\left(1-e^{-0.03 \cdot U_{\text {forward }}}\right)^{2.155}$

for woody PFTs and

$L_{\mathrm{B}, \text { grass }}=1.1+U_{\text {forward }}^{0.464}$ for herbaceous PFTs. $D_{\mathrm{T}}$ is the length (m) of the major axis, which in turn is the product of the rate of spread $R O S_{\mathrm{f}, \text { surface }}$ and fire duration (CFFBG, 1992). The estimated fire duration $(\mathrm{min})$ depends on the fire danger index:

$t_{\text {fire }}=\frac{241}{1+240 \cdot e^{-11.06 \cdot F D I}}$.

\subsubsection{Fractional combustion and fire intensity}

The intensity of a surface fire at the flaming front, $I_{\text {surface }}$ $\left(\mathrm{kW} \mathrm{m}^{-1}\right)$, is the product of rate of fire spread $\operatorname{ROS}_{\mathrm{f} \text {, surface }}$, fuel consumption $F C_{i}$ of the 1-h, 10-h and 100-h fuel classes and the heat content of the fuel $h$ (following Byram, 1959):

$I_{\text {surface }}=h \cdot \frac{\sum_{i=1}^{3} F C_{i}}{1000 \cdot A_{\mathrm{b}, \text { frac }}} \cdot \frac{R O S_{\mathrm{f}, \text { surface }}}{60}$,

where $A_{\mathrm{b}, \text { frac }}=A_{\mathrm{b}} / A$. The $F C_{i}$ are calculated as a function of fuel moisture for each fuel class using empirical equations based on Peterson and Ryan (1986), as described in Appendix B. When $I_{\text {surface }}<50 \mathrm{~kW} \mathrm{~m}^{-1}$, ignitions are extinguished. This rule is consistent with the minimal condition for sustained burning, as described by Pyne (1996).

\subsubsection{Fire damage to plants}

SPITFIRE considers crown scorch from surface fires. The scorch height $S H$ of the flame at which canopy scorching occurs increases with the $2 / 3$ power of $I_{\text {surface }}$ :

$S H=F \cdot I_{\text {surface }}^{0.667}$

(Peterson and Ryan, 1986; Dickinson and Johnson, 2001; Johnson, 1992; Agee, 1996). Field measurements and experiments in various ecosystems indicate little variation in the exponent. $F$ varies much more, and so is treated as a PFT-dependent parameter (Table 1). Assuming a cylindrical crown, the proportion $C K$ affected by a fire is:

$C K=\frac{S H-H+C L}{C L}$,

where $H$ is the height of the average individual of a given woody PFT and $C L$ is its crown length, a PFT-specific fraction of $H$ (Table 1). In the proportion $C K$ of the crown scorched by fire, all of the 1-, 10- and 100-h live fuel and $5 \%$ of the 1000-h live fuel are combusted (following Pyne et al., 1996). Mortality is determined based on the amount of damage to the crown, and to the cambium through heating of the bark. Assuming that these two major causes of post-fire mortality act independently, the total probability of mortality $P_{\mathrm{m}}$ is determined from the probabilities of mortality due to crown damage $P_{\mathrm{m}}(C K)$ and cambial damage $P_{\mathrm{m}}(\tau)$ :

$P_{\mathrm{m}}=P_{\mathrm{m}}(\tau)+P_{\mathrm{m}}(C K)-P_{\mathrm{m}}(\tau) \cdot P_{\mathrm{m}}(C K)$. 
The probability of mortality due to cambial damage is given by:

$P_{\mathrm{m}}(\tau)=\left\{\begin{array}{l}0, \frac{\tau_{l}}{\tau_{c}} \leq 0.22 \\ 0.563 \cdot \frac{\tau_{l}}{\tau_{c}}-0.125, \frac{\tau_{l}}{\tau_{c}}>0.22 \\ 1, \frac{\tau_{l}}{\tau_{c}} \geq 2.0\end{array}\right\}$,

where $\tau_{l} / \tau_{c}$ is the ratio of the residence time of the fire to the critical time for cambial damage (Peterson and Ryan, 1986). $\tau_{l}$ depends on $I_{\mathrm{R}}$, provided by the fire spread model (Rothermel, 1972; Wilson, 1982, see Appendix A), and total $F C_{i}$ for the 1-, 10- and 100-h fuels (Appendix B). The critical time for cambial damage $\tau_{c}(\mathrm{~min})$ depends on the bark thickness $B T(\mathrm{~cm})$ :

$\tau_{c}=2.9 \cdot B T^{2}$,

(Peterson and Ryan, 1986; Johnson, 1992), which is calculated from the diameter at breast height $(D B H, \mathrm{~cm})$ of the average individual using

$B T=\operatorname{par}_{1} \cdot D B H+$ par $_{2}$,

where par $_{1}$ and par $_{2}$ are PFT-specific constants (Table 1). The probability of mortality due to crown damage is:

$P_{\mathrm{m}}(C K)=r(C K) \cdot C K^{p}$,

where $r(C K)$ is a resistance factor between 0 and 1 , and $p$ is in the range of 3 to 4 based on defoliation studies cited by Peterson and Ryan (1986), Cochrane (2003) and Williams (1998) (Table 1). This approach allows capturing fire-adaptation strategies (e.g. savannah trees withstanding full crown scorching) vs. high fire sensitivity of rainforest trees on the one hand, and considers complete scorching of small trees vs. tall trees, which escape the flaming zone. The approach is based on North-American studies; assuming that the underlying functional relationship can be applied to other vegetation types.

If a tree is killed by fire but not combusted, the aboveground biomass is allocated to the appropriate dead fuel classes (1- to 1000-hr). This biomass decomposes the same way as the litter, and the undecomposed part is available for burning in the following year. The non-combusted belowground biomass is allocated to the belowground litter pool.

\subsubsection{Trace gas emissions}

Trace gas emissions result from the total amount of biomass burnt $B B$, which is the sum of dead and live fuel consumption as the result of surface fire and crown scorching. Using an emission factor $E F$ for each trace gas species $x$, the amount of trace gas species $M_{x}$ that is released into the atmosphere is given by

$M_{x}=\frac{E F_{x} \cdot B B}{[C]}$,

where $[C]$ is the conversion factor from carbon to biomass and the $E F_{x}$ are defined for each PFT. Andreae and Merlet
(2001, Andreae personal communication, 2003) gave emission factors for tropical forest, extratropical forest, and savanna and grassland. We have used the PFT composition of each of these biomes to attribute these to individual PFTs (Table 1). Thus, the value for tropical forest is attributed to tropical broadleaved evergreen trees, the value for savanna and grasslands is attributed to both herbaceous plants and tropical broadleaved raingreen trees, and the values for extratropical forests are attributed to other woody PFTs.

\subsection{Model application}

Fire processes in LPJ-SPITFIRE are simulated daily; emissions are calculated monthly; vegetation structure and composition are updated annually. The simulations were run on a $0.5^{\circ} \times 0.5^{\circ}$ grid using monthly maximum and minimum air temperature, precipitation, wet days, and cloud cover from the CRU05 database for 1901-2002. Monthly average wind speeds were obtained from NCEP re-analysis data and regridded to CRU for the period 1950-2002 (NOAA-CIRES Climate Diagnostics Center, Boulder, Colorado, USA, http: //www.cdc.noaa.gov/; Kalnay, 1996). Soil texture information was based on the FAO soil data base (FAO, 1991; Zobler, 1986). Annual atmospheric $\mathrm{CO}_{2}$ concentrations were as in McGuire et al. (2001). Values for $a\left(N_{\mathrm{d}}\right)$ were estimated from numbers of human-caused fires within the humid tropical biome in Indonesia (based on AVHRR, MODIS and ATSR, 1997-2003: RSS GmbH, unpublished), tropical savanna in northern Australia (AVHRR Fire Affected Area, 1997-2002, Western Australia Dept of Land Administration; unpublished), Mediterranean vegetation in Spain (Moreno et al., 1998), temperate forests in the western USA (ground observations, 1986-1996: Bureau of Land Management Fire Database; unpublished) and circumpolar boreal forests (Canadian Large Fire Database, 1959-1999; Stocks et al., 2002; AVHRR fire affected area Siberia and Central Asia, 1996-2002; Sukhinin et al., 2004). For regions where such data were not available, these values were extrapolated across similar biomes and land use types using methods described by Schultz et al. (2008). Human population densities were obtained from the HYDE V3 database (Klein Goldewijk, 2005), re-gridded to $0.5^{\circ}$ and linearly interpolated from decadal to annual resolution.

The model was run for 1000 years to bring the soil and vegetation carbon pools into equilibrium with climate, using a repetition of the first 30 years of the CRU climate data set and the first 30 years of the wind-speed data set. Only lightning-caused ignitions were simulated in the spinup phase. The model was then run in transient mode from 1901-2002 using the CRU historical climate data set (with the wind speed data from 1950-1999 also used for the first 49 years of the transient phase). During the transient phase both lightning- and human-caused ignitions were simulated, the latter changing with population density. 


\subsection{Model evaluation}

The MODIS Climate Modelling Grid (CMG) provides monthly data on active fires from November 2000 onwards at $0.5^{\circ}$ spatial resolution. The MODIS Active Fire Counts product (Giglio et al. 2006; http://modis-fire.umd.edu/MOD14. asp) was used to assess fire numbers and timing. This product indicates how many $1 \mathrm{~km}$ pixels within each $0.5^{\circ}$ grid cell were detected as having active fires (fire pixels) per month, with corrections for cloud cover and the presence of open water. MODIS captures fires burning during the day, but may miss ignitions which start mid-afternoon. Data from November 2000 to October 2002 are used in the evaluation. Following Giglio et al. (2006), our comparison focuses on grid cells having at least five fire counts in a single month and model grid cells with fire in at least one month during the observation period. The peak fire month is the one with the most fire counts. The fire season length is the number of months where the fire counts are at least $10 \%$ of the annual average.

The GBS product documents burnt area weekly from 1982 to 1999 at $8 \mathrm{~km} \times 8 \mathrm{~km}$ resolution based on changes in surface reflectance derived from the Pathfinder AVHRR Land (PAL) dataset (Carmona-Moreno et al., 2005). This product was used to assess simulated patterns of burnt area. We estimated burnt area from GBS on the $0.5^{\circ}$ model grid by multiplying the area of each grid cell by the number of detected $64 \mathrm{~km}^{2}$ fire pixels in that grid cell. The average area burnt between 1982 and 1999 was then compared with the simulated area burnt for the same interval. Both data and simulations were expressed as fractions of grid cell area per year. The Global Land Cover product GLC2000 (Bartholome and Belward, 2005) was used to exclude agricultural lands from the simulated burnt area. In making these comparisons we considered only grid cells in which both data and model showed burning.

GBS underestimates area burnt in boreal forests because of problems with cloudiness and canopy density (CarmonaMoreno et al., 2005). Sukhinin et al. (2004) developed an algorithm using hotspots from the thermal channel to verify fires to derive an AVHRR-based burnt area product for Eurasia, including the boreal regions of central Siberia and the arid continental interior. The Sukhinin data are available on a monthly basis for 1996-2002. We use these data in a supplementary assessment of burnt area in the boreal zone.

\section{Results}

\subsection{Simulated fire processes}

The simulated fire danger is zero in deserts and extreme cold areas (Fig. 3a), where the fuel load is too low for fires to start (Fig. 4a and b). Boreal, temperate and moist tropical regions are characterised by low to medium fire danger ( 0.2 to 0.6 , Fig. 4c) and seasonally dry regions have high to extremely
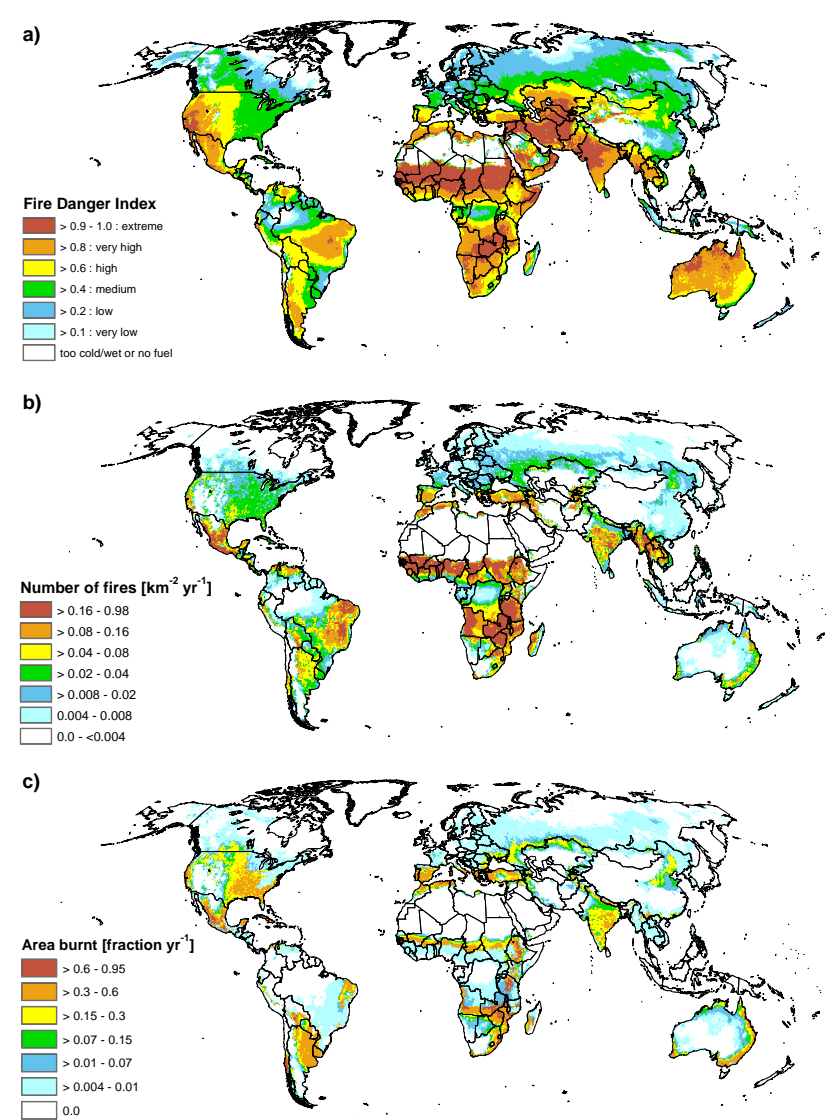

Fig. 3. Simulation results: (a) fire danger index, (b) number of fires, (c) fractional area burnt (all as annual averages for 1982-1999).

high fire danger $(>0.8$, Fig. $4 d)$. However, areas with low fuel load can have surface fire intensities too low to sustain fire so that, despite apparently high fire risks, fire starts (Fig. 3b) and burnt area (Fig. 3c) are minimal in these areas. Simulated fire numbers increase with increasing fire danger (Fig. 3a) with seasonally dry regions showing the most fires $\left(>0.16 \mathrm{~km}^{-2} \mathrm{yr}^{-1}\right)$. The simulated number of fires (Fig. 3b) is also influenced by human ignitions. There are relatively few simulated fires in populous regions of Europe, North America and India, for example. Single grid cells with high population density (urban centres) have few fires (0.004 to $0.02 \mathrm{~km}^{-2} \mathrm{yr}^{-1}$ ) despite high fire risk in neighbouring grid cells.

Simulated area burnt (Fig. 3c) is maximal in seasonally dry regions, particularly in savannas (Fig. 4d), and minimal in wet and/or cold regions (Fig. 4b). Whereas fire numbers are determined by the presence of fuel, lightning frequency, population density and surface fire intensity, fire spread (and hence area burnt) is driven by wind speed, fire duration and the amount, moisture content and characteristics of the fuel. As a result, the simulated spatial distribution of burnt area differs from that of fire numbers. In central South America central and western Africa and Indochina, for example, 

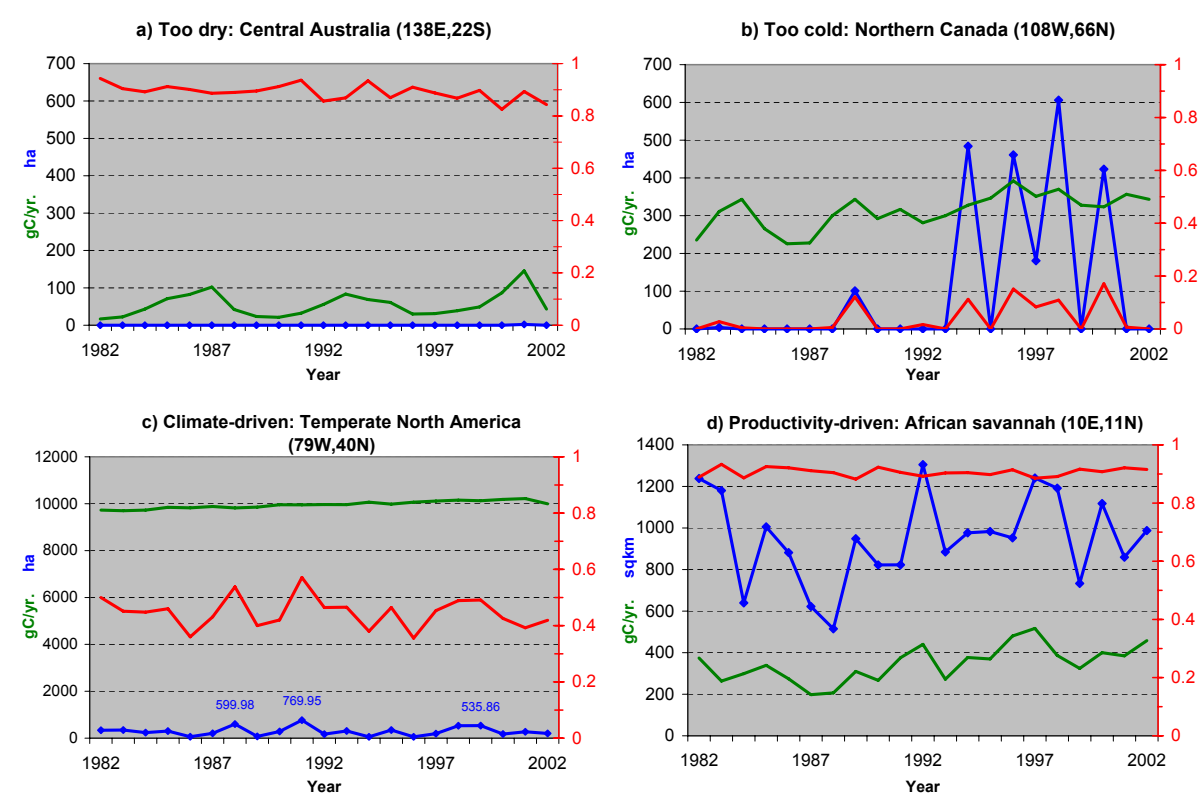

Fig. 4. Grid cell analysis of fuel vs. climate dynamics that determine area burnt in selected biomes 1982-2002; primary axis: annual area burnt (blue; please note different unit for panel (d)) and annual aboveground biomass (green); secondary axis: annual fire danger index (red).

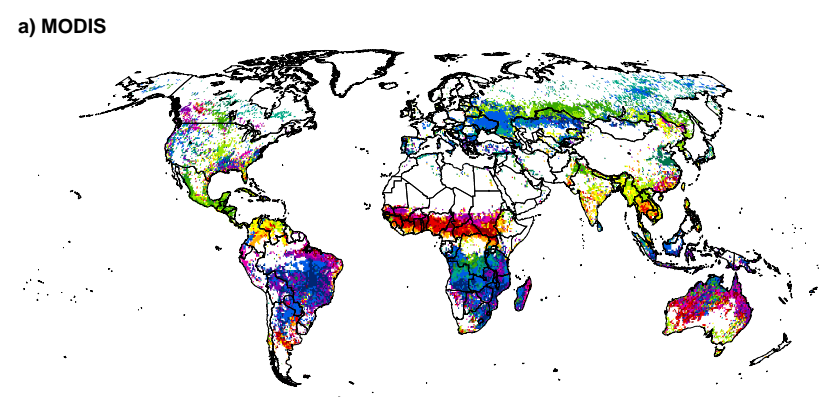

b) LPJ-SPITFIRE

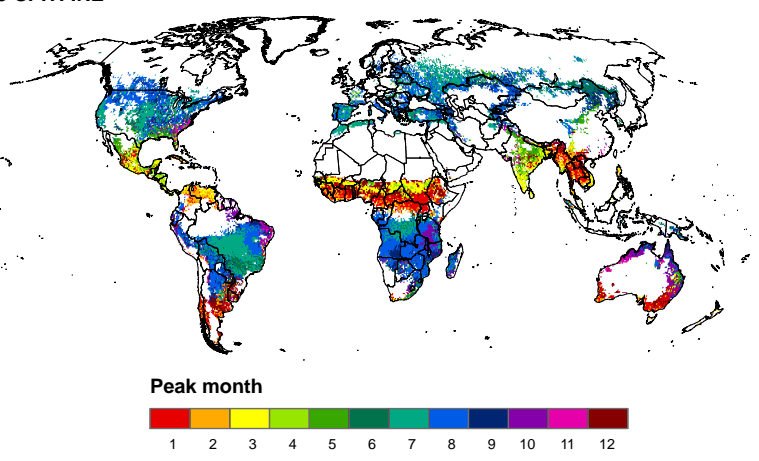

Fig. 5. (a) Observed (MODIS) and (b) simulated fire peak month, November 2000 to October 2002.

the influence of fuel characteristics on fire spread is key: the simulated burnt area is $<0.01 \mathrm{yr}^{-1}$ despite frequent ignitions $\left(0.02\right.$ to $\left.>0.16 \mathrm{~km}^{-2} \mathrm{yr}^{-1}\right)$ because the FBD is high. In contrast, along the west coast of the USA, along the western coasts of the Iberian Peninsula, and north and south of the Rio de la Plata estuary in South America, relatively few ignitions $\left(<0.08 \mathrm{~km}^{-2} \mathrm{yr}^{-1}\right)$ produce a simulated burnt area $\left(>0.3 \mathrm{yr}^{-1}\right)$ as high as that found in inland regions with much more frequent ignitions.

\subsection{Incidence and seasonal timing of fires}

MODIS data (Fig. 5a) show marked geographic patterns in the incidence and seasonal concentration of fires. Fires are infrequent in northern high latitudes and in arid regions (the Great Basin of western North America, the Sahara and Horn of Africa, central and southwest Asia, the Atacama and Kalahari and the continental interior of Australia). Fire incidence is also low in the wettest parts of the Amazonian and central African rain forests. These regions are well demarcated in the simulation (Fig. 5b) except that the model underestimates the fire-affected area of interior Australia, a region with exceptionally high interannual variability of precipitation (and fire). The lack of fire simulated by in central Australia stems from the extremely low vegetation production simulated by LPJ in this region, due to the low CRU rainfall input. The simulated extent of low fire incidence in the high northern latitudes is somewhat too large, extending southward to $50^{\circ} \mathrm{N}$ and encompassing the eastern Siberian region where MODIS shows fires, albeit infrequently. This could be due to the use of monthly climate data, which are then interpolated to quasi-daily values. A warm spell lasting for, say, a week would then be averaged out.

Observed patterns of seasonal timing in fire-prone regions, as detected by MODIS, are generally similar (i.e. offset by six calendar months) in the two hemispheres. Thus, the 
Length of fire season [month]

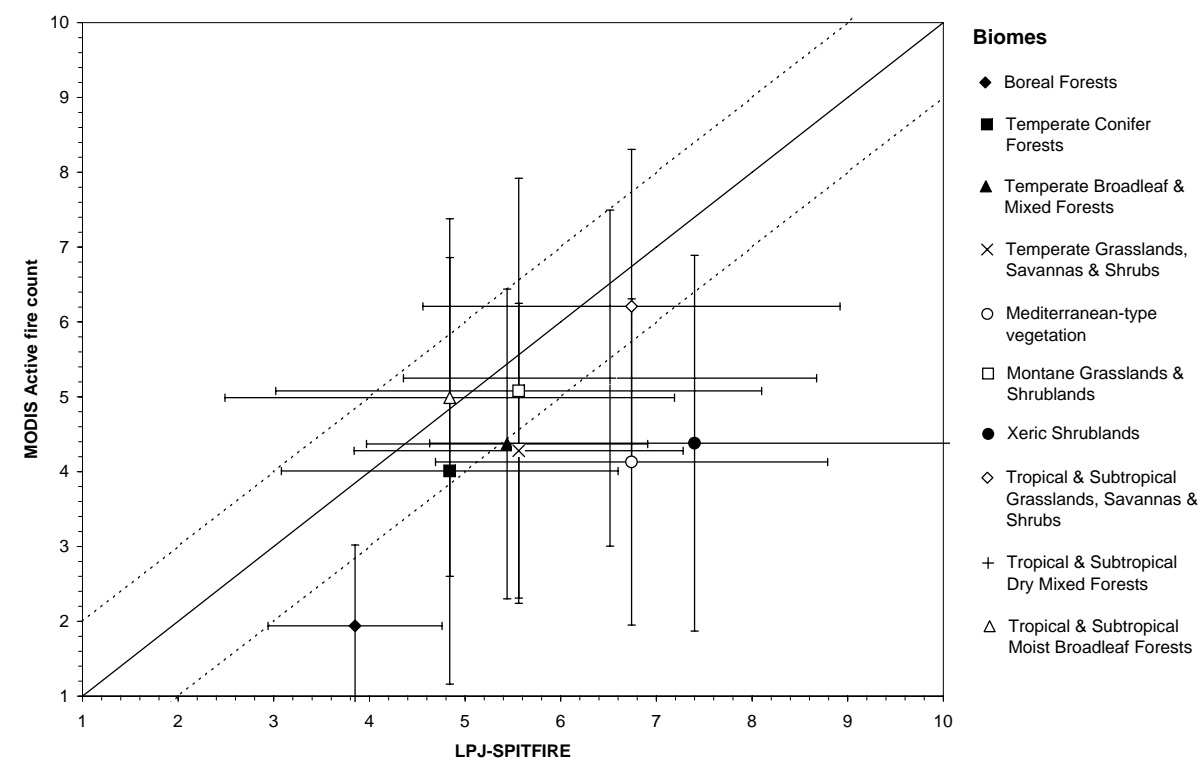

Fig. 6. Observed (MODIS) versus simulated fire season lengths for biomes.

tropics and subtropics in both hemispheres show winterspring fire maxima, reflecting summer rainfall regimes in which fuels dry out during the dry (winter) season. The mid- to high latitudes show summer-autumn fire maxima, reflecting winter rainfall dominance (Mediterranean-type climates) and/or climates in which drying conditions are confined to the warm (summer) season. The model (Fig. 5b) reproduces these broad features but with some offsets: the peak simulated fire season is about two months late in the Sahel, one month late in southern Africa and South America, and one to two months late in the southern part of the boreal zone. A correlation matrix was calculated from the covariance matrix which combined simulated peak month and MODIS. The resulting global correlation between MODIS peak month of fire activity and simulated peak month of fire activity was 0.43 .

MODIS detects fires in Indonesia that LPJ-SPITFIRE does not. This discrepancy could in part reflect the fact that CRU rainfall tends to be higher in the tropics than indicated by TRMM satellite-derived rainfall (Weber, 2006). However, it likely also reflects the fact that LPJ does not take account of recent land-use changes in this region, which are thought to have facilitated the spread of fires (Field et al., 2009; Langner and Siegert, 2009).

No fires are detected or simulated in the central Amazon region. However, the spatial extent of the fire-free region in the simulations is larger than shown by MODIS, pointing to deforestation and land conversion fires (Cardoso et al., 2003; Cochrane, 2003) - not captured by simulating wildfires in potential natural vegetation only - as the likely cause.

\subsection{Fire season length}

Simulated and satellite-detected fire season lengths, defined on a grid cell basis as in Giglio et al. (2006), were aggregated by biomes (following the classification of Olson et al., 2001, http://www.worldwildlife.org/science/ecoregions/ item1267.html). The mean length of the fire season increases from wet/cold to warm/dry biomes, both in the data and in the model (Fig. 6). The fire season is short (one to three months) in the boreal zone and longer (four to seven months) in semi-arid and highly seasonal climates. The model reproduces these differences, but shows a general tendency to over-estimate fire season length.

Simulated fire season length in montane and tropical grasslands, and in tropical and subtropical moist broadleaf forests, matches well the satellite-detected fire season length. Temperate forest biomes and temperate grasslands show a 1month longer fire season length in the simulation, while boreal forest, xeric shrublands and Mediterranean biomes shown a 2-3 month longer fire season in the simulation. The observed standard deviations of fires season length range between less than 1 month (boreal forest) and nearly 3 months (xeric shrubland); the model captures these differences. The global correlation between observed and simulated fire season lengths was 0.53 .

\subsection{Burnt area}

The model simulates at least some burnt area in $54 \%$ of land grid cells. About a fifth of these are shown as fire-free in the GBS data (Fig. 7). Most of these grid cells however are in the boreal zone, where GBS is known to underestimate 


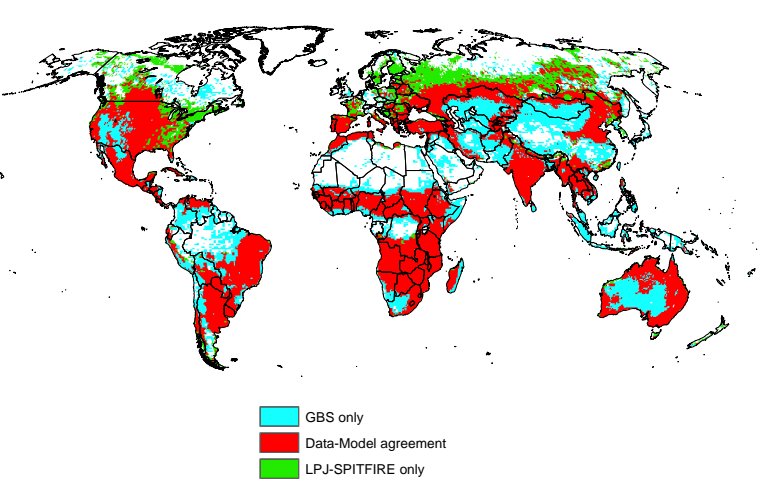

Fig. 7. Comparison of simulated and observed (GBS) area burnt, 1982-1999. Red areas: both GBS and the model show fires. Blue areas: GBS sees fires, while none are simulated. Green areas: the model simulates fires, while none are seen by GBS.
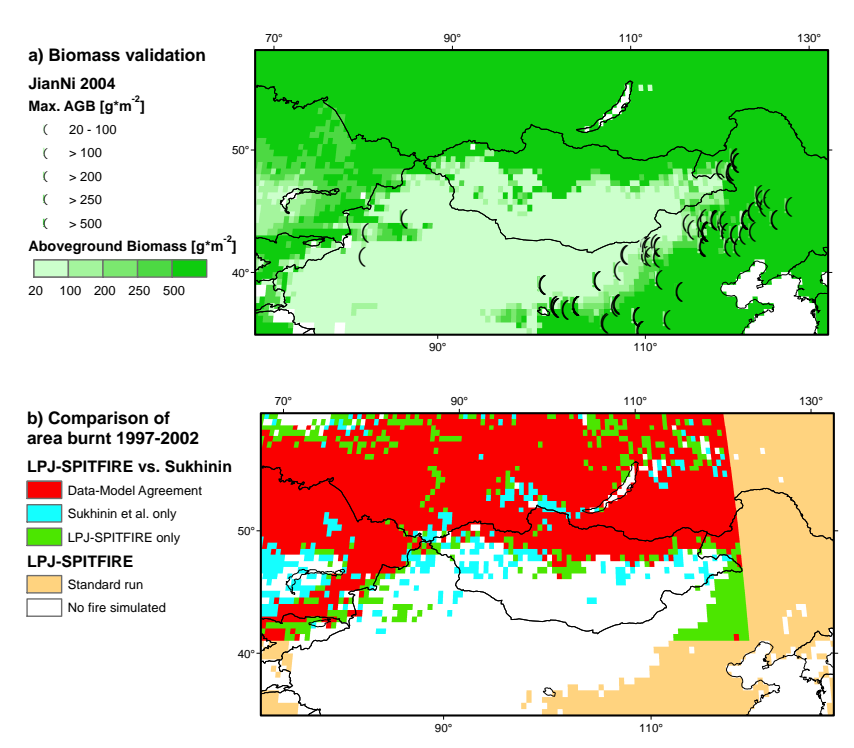

Fig. 8. (a) Comparison of observed (Ni, 2004) and simulated net primary production in northern China. (b) Comparison of observed (Sukhinin et al., 2004) and simulated area burnt for 1997-2002, following the conventions of Fig. 7.

fire incidence (Carmona-Moreno et al., 2005). Sukhinin et al. (2004) show greater burnt area than GBS in the boreal zone.

GBS detects fires in some arid ecosystems that are not simulated by the model, and not detected by MODIS. "Burnt" areas shown by GBS in the Sahara desert and on the Arabian Peninsula are well-known false positives (Carmona-Moreno et al., 2005). In other regions where GBS shows fires and the model does not, the climatic fire danger is high ( 0.6 to $>0.8$ ) (Fig. 3a). One explanation for the discrepancy might be that the simulated fuel load is too low, preventing fires from spreading. However, comparison with extensive field measurements in northern China (Ni, 2004) suggests that the model estimates net primary production (NPP) reasonably
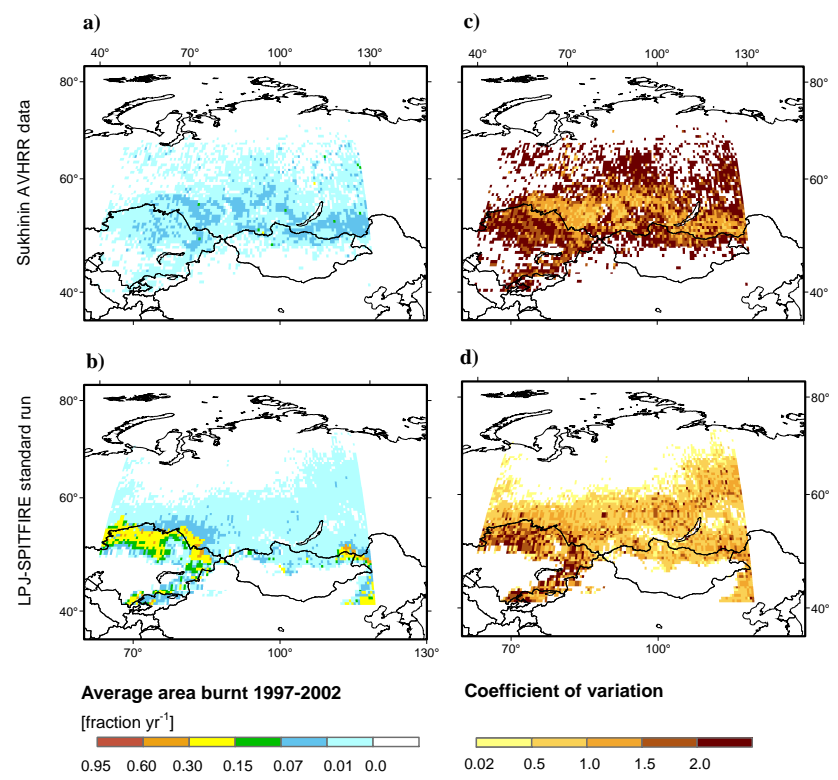

Coefficient of variation

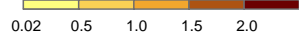

Fig. 9. Comparison of (a) observed (Sukhinin et al., 2004) and (b) simulated annual average area burnt in central Siberia; (c), (d) observed and simulated coefficients of variation in area burnt.

well in this region (Fig. 8a). It therefore seems likely that the simulated fuel load is realistic, while GBS is in error. Support for this inference comes from the observation that the spatial limits of the simulated burnt area broadly match those detected by Sukhinin et al. (2004) north of $40^{\circ} \mathrm{N}$ (Fig. 8b). Country statistics and MODIS fire counts (Fig. 5a) also indicate fire in northern, central and eastern Mongolia, but not in southern Mongolia or central Asia (FAO, 2006).

Sukhinin et al. (2004) show a large region of Siberia with fires but with the annual area burnt $<0.01$, increasing to 0.07 in the central and southern boreal zone (Fig. 9a). The simulated burnt area compares well with Sukhinin et al. (2004) for most of the mid-continental boreal zone (Fig. 9b), except for the region between Lake Baikal and the Yenisei River and in Kazakhstan. The model simulates a gradual increase in area burnt moving from the northern to the southern boreal zone, where typical simulated values are 0.15 to 0.3 (compared to observed values $<0.07$ ). The coefficient of variation of the Sukhinin et al. (2004) burnt area data is highest in the northern boreal and the southern fringe of the boreal zone and lowest in the central boreal zone (Fig. 9c). The interannual variability of simulated area burnt is generally less pronounced than that observed (Fig. 9d), that is, the model tends to miss the large burnt areas in the most extreme years.

\subsection{Global patterns in simulated pyrogenic emissions}

The simulated average annual $\mathrm{CO}_{2}$ release from biomass burning during the 1980s and 1990s amounts to $3.45 \mathrm{PgC} \mathrm{yr}^{-1}$ with an interannual variability (1 s.d.) of about $7 \%$. When the proportion of natural vegetation in 
Table 2. Comparison of estimates of global annual $\mathrm{CO}_{2}$ release $\left[\mathrm{PgC} \mathrm{yr}^{-1}\right]$.

\begin{tabular}{|c|c|c|c|c|c|c|}
\hline \multicolumn{2}{|c|}{ 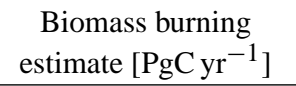 } & \multirow[t]{2}{*}{$\begin{array}{l}\text { Study } \\
\text { period }\end{array}$} & \multirow[t]{2}{*}{$\begin{array}{l}\text { Method to } \\
\text { estimate area burnt }\end{array}$} & \multirow{2}{*}{$\begin{array}{l}\text { Method used } \\
\text { to estimate } \\
\text { biomass } \\
\text { burning } \\
\text { emissions }\end{array}$} & \multirow[t]{2}{*}{$\begin{array}{l}\text { Representation } \\
\text { of vegetation }\end{array}$} & \multirow[t]{2}{*}{ Reference } \\
\hline $\begin{array}{l}\text { Potential } \\
\text { natural }\end{array}$ & $\begin{array}{l}\text { Actual } \\
\text { vegetation } \\
\text { vegetation }\end{array}$ & & & & & \\
\hline 3.87 & 2.31 & $\begin{array}{l}\text { Late } \\
1990 s\end{array}$ & n.a. & $\begin{array}{l}\text { (Seiler and } \\
\text { Crutzen, } \\
1980 \text { ) }\end{array}$ & n.a. & $\begin{array}{l}\text { (Andreae and } \\
\text { Merlet, 2001) }\end{array}$ \\
\hline- & 2.46 & $\begin{array}{l}1997- \\
2004\end{array}$ & $\begin{array}{l}\text { fire activity data } \\
\text { (TRMM-VIRS, } \\
\text { ERS-ATSR, } \\
\text { MODIS), MODIS } \\
\text { burnt area and } \\
\text { country statistics } \\
\text { for burnt area }\end{array}$ & $\begin{array}{l}\text { (van der } \\
\text { Werf et al., } \\
\text { 2003) }\end{array}$ & CASA model & $\begin{array}{l}\text { (van der Werf } \\
\text { et al., 2006) }\end{array}$ \\
\hline- & 1.71 & $\begin{array}{l}1960- \\
2000\end{array}$ & $\begin{array}{l}\text { inventory } \\
\text { (combination of } \\
\text { literature } \\
\text { information, model } \\
\text { results and } \\
\text { observations) }\end{array}$ & $\begin{array}{l}\text { (Seiler and } \\
\text { Crutzen, 1980) }\end{array}$ & $\begin{array}{l}\text { inventory } \\
\text { (combination of } \\
\text { literature } \\
\text { information, } \\
\text { model results } \\
\text { and } \\
\text { observations) }\end{array}$ & $\begin{array}{l}\text { (Schultz et al., } \\
\text { 2008) }\end{array}$ \\
\hline- & 1.74 & 2000 & $\begin{array}{l}\text { GLOBSCAR area } \\
\text { burnt }\end{array}$ & $\begin{array}{l}\text { (Seiler and } \\
\text { Crutzen, 1980) }\end{array}$ & $\begin{array}{l}\text { LPJ-DGVM } \\
\text { output }\end{array}$ & $\begin{array}{l}\text { (Hoelzemann } \\
\text { et al., 2004) }\end{array}$ \\
\hline- & 2.29 & 2000 & GBA 2000 & $\begin{array}{l}\text { (Seiler and } \\
\text { Crutzen, 1980) }\end{array}$ & $\begin{array}{l}\text { Tree cover: AVHRR } \\
\text { (DeFries et al., } \\
\text { 2000) and MODIS } \\
\text { (Hansen et al., } \\
\text { 2003), } \\
\text { biomass: from } \\
\text { literature and } \\
\text { AVHRR } \\
\text { NDVI } \\
\text { (Myneni et al., } \\
\text { 2001) }\end{array}$ & $\begin{array}{l}\text { (Ito and } \\
\text { Penner, 2004) }\end{array}$ \\
\hline 3.54 & 2.24 & 1982-2002 & SPITFIRE & SPITFIRE & LPJ-DGVM & this study \\
\hline
\end{tabular}

each $0.5^{\circ}$ grid cell is reduced to exclude croplands, the simulated average $\mathrm{CO}_{2}$ release is reduced to $2.24 \mathrm{PgC} \mathrm{yr}^{-1}$. The land-cover correction is made after the simulation is completed, so the implied changes in vegetation cover do not influence the simulated fire regimes.

These amounts apply to direct emissions from fires. In common with other published estimates (Table 2) they do not include additional $\mathrm{CO}_{2}$ released from the subsequent decomposition of unburnt litter generated through fire-induced mortality; this emission is not separately tracked by the model.

The amount of carbon released annually by fires is not known with precision. The model estimate lies within the range of published estimates (Table 2). The model estimate before exclusion of croplands is close to an independent estimate of potential $\mathrm{CO}_{2}$ emissions (3.87 $\mathrm{PgC} \mathrm{yr}^{-1}$ ) by Andreae and Merlet (2001) (Table 2). With standard emission factors applied, the model simulates mean annual emissions of $8200 \mathrm{TgCO}_{2}, 448 \mathrm{TgCO}, 19 \mathrm{Tg} \mathrm{CH}_{4}, 24 \mathrm{Tg} \mathrm{VOC}$, $70 \mathrm{Tg} \mathrm{TPM}$, and $15 \mathrm{Tg} \mathrm{NO}_{\mathrm{x}}$. These amounts are inevitably in broad agreement with other estimates (Table 3), given that the simulated emission of $\mathrm{CO}_{2}$ is consistent with other studies (Table 2) and that similar emission factors have been applied. In reality, the amounts of trace gases released per unit of $\mathrm{CO}_{2}$ must vary, for example according to fire intensity 
Table 3. Comparison of estimates of trace gas emissions $\left(\mathrm{Tg} \mathrm{yr}^{-1}\right)$.

\begin{tabular}{lccccccl}
\hline $\begin{array}{l}\text { Study } \\
\text { period }\end{array}$ & $\mathrm{CO}_{2}$ & $\mathrm{CO}$ & $\mathrm{CH}_{4}$ & $\mathrm{VOC}$ & $\mathrm{TPM}$ & $\mathrm{NO}_{\mathrm{x}}$ & Reference \\
\hline 2000 & 8400 & 496 & 32 & 38 & n.a. & n.a. & (Ito and Penner, 2004) \\
\hline Late 1990s & 8200 & 413 & 19 & 25 & 49 & 12 & $\begin{array}{l}\text { (Andreae and Merlet, } \\
\text { 2001; M. O. Andreae, } \\
\text { personal communication, } \\
\text { 2003) }\end{array}$ \\
\hline $1997-2004$ & 8900 & 433 & 21 & n.a. & n.a. & n.a. & $\begin{array}{l}\text { (van der Werf et al., } \\
\text { 2006) }\end{array}$ \\
\hline 2000 & 5700 & 271 & 13 & 9 & n.a. & 8 & $\begin{array}{l}\text { (Hoelzemann et al., } \\
\text { 2004) }\end{array}$ \\
\hline $1982-2002$ & 8200 & 448 & 19 & 24 & 70 & 15 & this study \\
\hline
\end{tabular}

(with smouldering combustion producing a larger fraction of reduced species than flaming combustion). Such differences could be simulated within the existing model structure, if globally applicable data on changes in the trace gas mixture with the energy content of the fire and moisture conditions of the combusted fuel (e.g. Saarnak, 2001; Hély et al., 2003a) were available.

\section{Discussion}

LPJ-SPITFIRE follows the concepts for process-based fire modelling put forward by Fosberg et al. (1999) and Keane et al. (2004) in that it explicitly considers the influence of fuel characteristics by weighting the relative proportion of fine and coarse fuels for the rate of depletion of fuel moisture, which influences in turn both fire risk and rate of spread. LPJ/Reg-FIRM (Venevsky et al., 2002) uses the Telitsyn formula, a simplification of the Rothermel equations (Telitsyn, 1988; Telitsyn, 1996), to predict the rate of fire spread. LPJSPITFIRE includes the full Rothermel model, which not only allows the calculation of surface fire intensity, but also derivation of the residence time of the flames - essential for the calculation of fire-induced crown and cambial damage. These two main causes of post-fire mortality are included in SPITFIRE, comparable to the functionality captured in MCFIRE. LPJ-SPITFIRE includes PFT parameters to describe the influence of fuel characteristics on fire spread and the influence of tree architecture on the effects of fire (Figs. 1 and 2, Table 1). Fire effects, which are specific to multi-stem shrubs in subtropical and tropical climates, are not captured by the present set of PFTs and might explain some of the overestimation of fire, where open grassland is simulated instead of shrubland. The version of LPJ applied in this study simulates only single-stem woody vegetation which can be regarded as shrubs when tree height is low. The dependence of fire duration on weather conditions, landscape heterogeneity and fire suppression is a key area for model development: the simple approach of Eq. (14) does not allow for longlasting fires, which may be one contributing factor to the underestimation of burnt area in boreal forest regions. Failure to account for landscape heterogeneity may contribute to the model's overestimation of fire elsewhere. Self-generated uplift wind-conditions in large fires can potentially improve the simulation of fire under extreme climate conditions in coupled climate-vegetation-fire models.

The performance of LPJ-SPITFIRE in evaluations against data is encouraging and opens up many potentially fruitful applications. One is the prediction of the consequences of climate change for fire regimes, vegetation and pyrogenic trace-gas and particulate emissions. The recent growth of information documenting changes of fire regimes on historical and geologic timescales (see e.g. Power et al., 2008; Marlon et al., 2008, 2009) suggests that the model might also be a useful tool for understanding the long-term controls on fire regimes and vegetation changes, including the interplay between natural and human influences on these regimes. The investigation of pyrogenic feedback to the climate will ultimately require incorporating the dynamics of vegetation and fire, as encapsulated by LPJ-SPITFIRE, within an Earth System model. Some initial steps towards quantifying the magnitude of this feedback could be obtained by an asynchronous coupling between LPJ-SPITFIRE and a coupled ocean-atmosphere model. Other potential applications include seasonal forecasting of fire activity and emissions from biomass burning, and investigating land/fire management strategies at regional scales. 
Table A1. Additional equations and variables of the fire spread model.

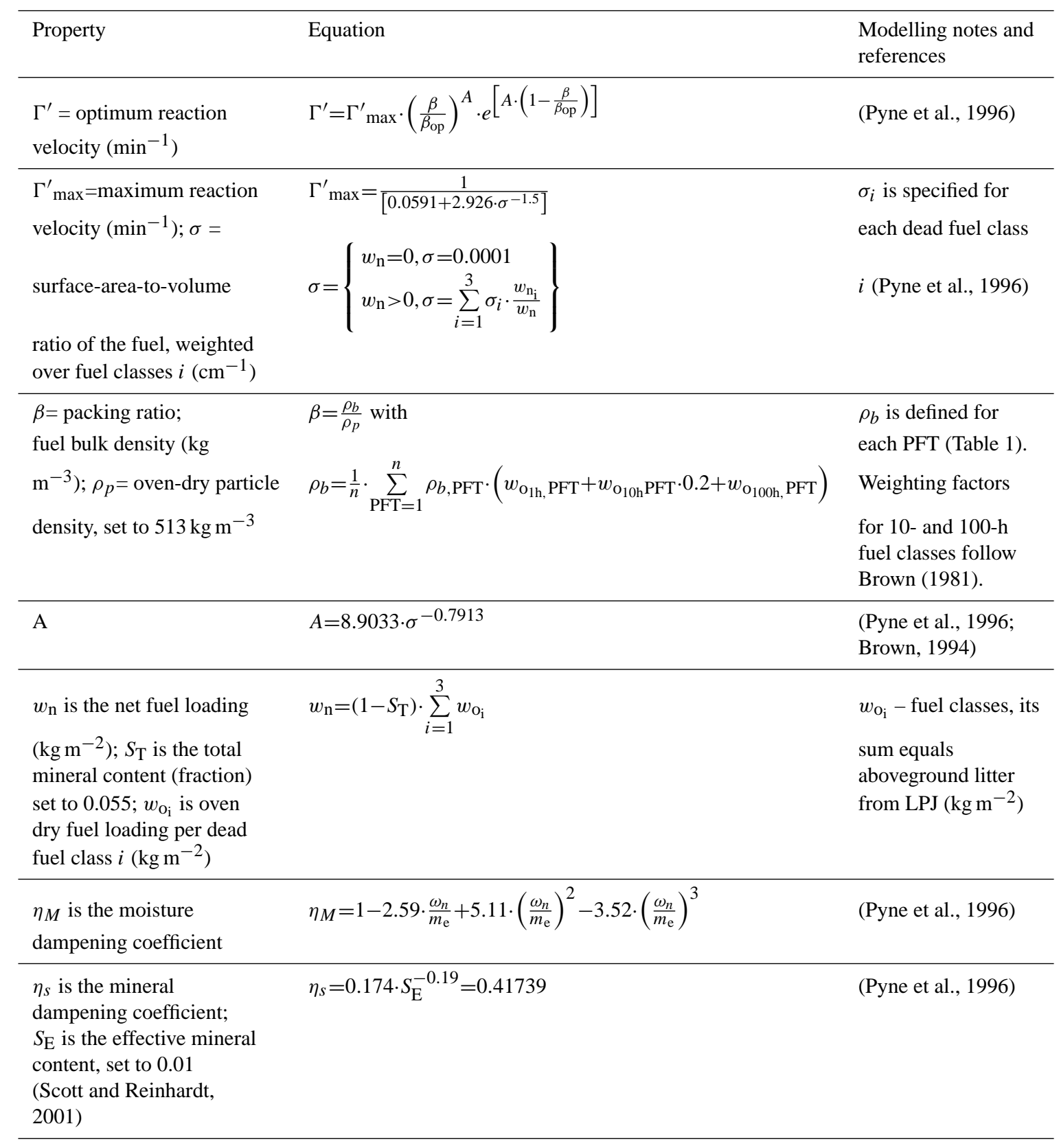

\section{Appendix A}

\section{Additional equations of fire spread}

$I_{\mathrm{R}}$ is the product of five terms whose calculation is detailed in Table A1:

$I_{\mathrm{R}}=\Gamma^{\prime} \cdot w_{\mathrm{n}} \cdot h \cdot \eta_{M} \cdot \eta_{S}$,

where $\Gamma^{\prime}$ is the optimum reaction velocity $\left(\mathrm{min}^{-1}\right), w_{\mathrm{n}}$ is the net fuel load $\left(\mathrm{kg} \mathrm{m}^{-2}\right)$ (the amount of fuel after subtraction of its mineral content), $h$ is the heat content of the fuel $\left(18000 \mathrm{~kJ} \mathrm{~kg}^{-1}\right), \eta_{M}$ is a moisture-dampening coefficient (which declines to zero when $\omega_{o}=m_{\mathrm{e}}$ ), and $\eta_{S}$ is a mineral-dampening coefficient.

$\xi$ is given by:

$\xi=\frac{e^{(0.792+3.7597 \cdot \sqrt{\sigma})(\beta+0.1)}}{192+7.9095 \cdot \sigma}$,

where $\sigma$ and $\beta$ are weighted averages of the surface-area-tovolume ratio and the packing ratio, respectively, of the fuel classes. 
$\varepsilon$ is given by:

$\varepsilon=e^{\left(\frac{-4.528}{\sigma}\right)}$.

$Q_{\text {ig }}$ is given by:

$Q_{\text {ig }}=581+2594 \cdot \omega_{l}$.

where $\omega_{l}$ is fuel moisture content.

$\Phi_{W}$ is given by:

$\Phi_{w}=C \cdot\left(3.281 \cdot U_{\text {forward }}\right)^{B} \cdot\left(\frac{\beta}{\beta_{o p}}\right)^{-E}$,

where $U_{\text {forward }}$ is the forward wind speed $\left(\mathrm{m} \mathrm{min}^{-1}\right)$, and $\beta_{o p}, B, C$ and $E$ are functions of $\sigma$ :

$\beta_{o p}=0.200395 \cdot \sigma^{-0.8189}$,

$B=0.15988 \cdot \sigma^{0.54}$,

$C=7.47 \cdot e^{\left(-0.8711 \cdot \sigma^{0.55}\right)}$

and

$E=0.7515 \cdot e^{(-0.01094 \cdot \sigma)}$.

\section{Appendix B}

\section{Fractional consumption of different fuel classes as functions of moisture content}

\section{B1 Consumption of dead fuel}

The equations for surface fuel consumption follow the methodology of Peterson and Ryan (1986). The proportion of each dead fuel class that is consumed decreases as its moisture content relative to its moisture of extinction $m_{\mathrm{e}}$ increases. For the 1-h class:

$F C_{1 \mathrm{~h}}=\left\{\begin{array}{l}1.0, \frac{\omega_{o, l}}{m_{\mathrm{e}}} \leq 0.18 \\ 1.2-0.62 \cdot \frac{\omega_{o, l}}{m_{\mathrm{e}}}, 0.18 \leq \frac{\omega_{o, l}}{m_{\mathrm{e}}} \leq 0.73 \\ 2.45-2.45 \cdot \frac{\omega_{o, l}}{m_{\mathrm{e}}}, \frac{\omega_{o, l}}{m_{\mathrm{e}}}>0.73\end{array}\right\}$

$\cdot w_{\mathrm{o}_{\mathrm{hh}}} \cdot A_{\mathrm{b}, \text { frac }}$,

where $F C_{1 \mathrm{~h}}$ is the amount of dead fuel consumed per $\mathrm{m}^{2}, \omega_{l g}$ is moisture content weighted among live grass and dead fuel, $w_{\mathrm{o}_{\mathrm{h}}}$ is the fuel load, and $A_{\mathrm{b} \text {,frac }}$ is the fractional area burnt. Live grass fuel moisture content depends on the soil moisture content of the upper soil layer $\omega_{s, 1}$ :

$\omega_{l g}=\max \left(0, \frac{10}{9} \omega_{s, 1}-\frac{1}{9}\right)$

and is combined with the moisture content of the 1-h fuel as follows:

$\omega_{n, l}=\omega_{n}+\omega_{l g} \cdot \frac{w_{\text {livegrass }}}{w_{\mathrm{o}_{\mathrm{hh}}}}$.
For the 10- and 100-h classes:

$F C_{10 \mathrm{~h}}=\left\{\begin{array}{l}1.0, \frac{\omega_{o}}{m_{\mathrm{e}}} \leq 0.12 \\ 1.09-0.72 \cdot \frac{\omega_{o}}{m_{\mathrm{e}}}, 0.12 \leq \frac{\omega_{o}}{m_{\mathrm{e}}} \leq 0.51 \\ 1.47-1.47 \cdot \frac{\omega_{o}}{m_{\mathrm{e}}}, \frac{\omega_{o}}{m_{\mathrm{e}}}>0.51\end{array}\right\}$

- $w_{\mathrm{o}_{10 \mathrm{~h}}} \cdot A_{\mathrm{b}, \mathrm{frac}}$,

and

$F C_{100 \mathrm{~h}}=\left\{\begin{array}{l}0.98-0.85 \cdot \frac{\omega_{o}}{m_{\mathrm{e}}}, \frac{\omega_{o}}{m_{\mathrm{e}}} \leq 0.38 \\ 1.06-1.06 \cdot \frac{\omega_{o}}{m_{\mathrm{e}}}, \frac{\omega_{o}}{m_{\mathrm{e}}}>0.38\end{array}\right\}$

- $w_{\mathrm{o}_{100 \mathrm{~h}}} \cdot A_{\mathrm{b}, \mathrm{frac}}$.

Assuming that not more than $80 \%$ of the 1000 -h dead fuel is consumed in a surface fire, $F C_{1000 \mathrm{~h}}$ is obtained as

$F C_{1000 \mathrm{~h}}=-0.8 \cdot \frac{\omega_{o}}{m_{\mathrm{e}}}+0.8$.

The consumption of 1000-h fuels does not influence fire spread or intensity (Pyne et a., 1996).

\section{B2 Consumption of live fuel}

In the proportion $(C K)$ of the crown scorched by fire, $100 \%$ of the 1-h live fuels (i.e. leaves and twigs) and $5 \%$ of the 10-h fuels (i.e. small branches) are consumed by fire. We assume that none of the 100-h (large branches) or 1000-h fuels (tree trunks) are consumed by crown scorch (Pyne et al., 1996; Stocks et al., 2004). Leaves are not consumed immediately in an active combustion process, but the affected leaves are killed and removed from the living biomass pool. As a simplifying assumption, these leaves are added to the combustion term. The simulation of active crown fires and resulting biomass combustion is currently impossible given the absence of an explicit crown structure in the LPJ model and the application of quasi-daily values of temperature, which are linearly interpolated from monthly climate input. Incorporating these features would require developing new formulations of carbon allocation, tree architecture and population dynamics in LPJ and extension of the weather generator to joint distributions of temperature and rainfall. 
Talbe C1. List of model variables and parameters.

\begin{tabular}{|c|c|c|}
\hline Variable & Description & Unit \\
\hline$A$ & area of grid cell & ha \\
\hline$a\left(N_{\mathrm{D}}\right)$ & Rate of human-caused ignitions per person & ignitions individual ${ }^{-1} \mathrm{~d}^{-1}$ \\
\hline$A_{\mathrm{b}}$ & Area burnt in a grid cell & had $^{-1}$ \\
\hline$A_{\mathrm{b}, \text { frac }}$ & Fractional area burnt & - \\
\hline $\bar{a}_{\mathrm{f}}$ & Mean fire area & ha \\
\hline$B B$ & Total biomass burning & $\mathrm{gC} \mathrm{m}^{-2}$ \\
\hline$B T$ & Bark thickness & $\mathrm{cm}$ \\
\hline$C K$ & Fraction of crown scorch & - \\
\hline$C L$ & Crown length of woody PFT & $\mathrm{m}$ \\
\hline$D_{\mathrm{T}}$ & Total distance travelled & $\mathrm{m}$ \\
\hline$D B H$ & Diameter at breast height & $\mathrm{cm}$ \\
\hline$E\left(n_{h, i g}\right)$ & Expected number of human-caused ignitions & $\mathrm{ha}^{-1} \mathrm{~d}^{-1}$ \\
\hline$E\left(n_{i g}\right)$ & Expected number of ignition events & $\mathrm{ha}^{-1} \mathrm{~d}^{-1}$ \\
\hline$E\left(n_{1, \mathrm{ig}}\right)$ & Expected number of lightning-caused ignitions & $\mathrm{ha}^{-1} \mathrm{~d}^{-1}$ \\
\hline$E F_{\mathrm{X}}$ & Emission factor for trace gas species $\mathrm{x}$ & - \\
\hline$F^{\wedge}$ & PFT-parameter in crown scorch equation & - \\
\hline FC & Total dead fuel consumed in a surface fire & $\mathrm{g} \mathrm{DM} \mathrm{m}^{-2}$ \\
\hline$F C_{\mathrm{i}}$ & Fuel consumption of $1-, 10-$ and $100-\mathrm{h}$ fuel class & $\mathrm{g} \mathrm{DM} \mathrm{m}^{-2}$ \\
\hline FDI & Fire danger index & - \\
\hline$h$ & Calorific heat content & $\mathrm{kJ} \mathrm{kg}^{-1}$ \\
\hline$H$ & Tree height & $\mathrm{m}$ \\
\hline$I_{\mathrm{R}}$ & Reaction intensity & $\mathrm{kJ} \mathrm{m}^{-2} \min ^{-1}$ \\
\hline$I_{\text {surface }}$ & Surface fire intensity & $\mathrm{kW} \mathrm{m}^{-1}$ \\
\hline$k\left(P_{\mathrm{D}}\right)$ & Spatial dependence of human-caused ignitions & - \\
\hline$L_{\mathrm{B}, \text { tree }}$ & $\begin{array}{l}\text { Length-to-breath ratio of the ellipse for } \\
\text { fractional cover of woody PFTs }\end{array}$ & - \\
\hline$L_{\mathrm{B}, \text { grass }}$ & $\begin{array}{l}\text { Length-to-breath ratio of the ellipse for } \\
\text { fractional cover of herbaceous PFTs }\end{array}$ & - \\
\hline$m_{\mathrm{e}}$ & Moisture of extinction & - \\
\hline$M_{\mathrm{X}}$ & $\begin{array}{l}\text { Amount of trace gas emitted for species } \mathrm{X} \\
\left(\mathrm{X}=\mathrm{CO}_{2}, \mathrm{CO}, \mathrm{CH}_{4}, \mathrm{TPM}, \mathrm{VOC}, \mathrm{NO}_{\mathrm{X}}\right)\end{array}$ & $\mathrm{g} \mathrm{X} \mathrm{m}^{-2}$ \\
\hline$n_{\mathrm{h}, \mathrm{ig}}$ & Rate of human-caused ignitions & $\mathrm{ha}^{-1} \mathrm{~d}^{-1}$ \\
\hline$n_{1, \text { ig }}$ & Rate of lightning-caused ignitions & $\mathrm{ha}^{-1} \mathrm{~d}^{-1}$ \\
\hline$N I(d)$ & Nesterov Index & ${ }^{\circ} \mathrm{C}^{2}$ \\
\hline$p$ & $\begin{array}{l}\text { Parameter for woody PFTs used in } \\
P_{\mathrm{m}}(C K) \text { equation }\end{array}$ & - \\
\hline$P_{\mathrm{b}}$ & probability of fire per unit time & $\mathrm{d}^{-1}$ \\
\hline$P_{\mathrm{D}}$ & Human population density & individuals $\mathrm{km}^{-2}$ \\
\hline$P_{\mathrm{m}}(C K)$ & Probability of mortality as a result of crown scorching & - \\
\hline$P_{\mathrm{m}}(\tau)$ & Probability of mortality by cambial damage & - \\
\hline$P_{\mathrm{m}}$ & Probability of post-fire mortality & - \\
\hline par $_{1}$, par $_{2}$ & $\begin{array}{l}\text { Parameters for woody PFTs used in bark } \\
\text { thickness calculation }\end{array}$ & - \\
\hline$Q_{\text {ig }}$ & Heat of pre-ignition & $\mathrm{kJ} \mathrm{kg}^{-1}$ \\
\hline $\operatorname{ROS}_{\mathrm{f}, \text { surface }}$ & Forward rate of spread of a surface fire & $\mathrm{m} \mathrm{min}^{-1}$ \\
\hline $\operatorname{ROS}_{\mathrm{b}, \text { surface }}$ & Backward rate of spread of a surface fire & $\mathrm{mmin}^{-1}$ \\
\hline$r(C K)$ & Resistance factor against crown damage & - \\
\hline $\mathrm{SH}$ & Scorch height & $\mathrm{m}$ \\
\hline$T_{\mathrm{dew}}(d)$ & Daily dew point temperature & ${ }^{\circ} \mathrm{C}$ \\
\hline$T_{\max }(d)$ & Daily maximum air temperature & ${ }^{\circ} \mathrm{C}$ \\
\hline$T_{\min }(d)$ & Daily minimum air temperature & ${ }^{\circ} \mathrm{C}$ \\
\hline$t_{\text {fire }}$ & Fire duration & $\min$ \\
\hline$U_{\text {forward }}$ & Forward wind speed & $\operatorname{m~min}^{-1}$ \\
\hline$w_{\mathrm{o}}$ & Total dead fuel load & $\mathrm{g} \mathrm{DM} \mathrm{m}^{-2}$ \\
\hline & Dead fuel load in 1-, 10-, 100-h fuel class & $\mathrm{g} \mathrm{DM} \mathrm{m}^{-2}$ \\
\hline \multicolumn{3}{|c|}{ Greek symbols used } \\
\hline$\alpha_{i}$ & Drying parameter for $1-, 10-$ and 100 -h fuel classes & ${ }^{\circ} \mathrm{C}^{-2}$ \\
\hline$\Gamma$ & Reaction velocity & $\min ^{-1}$ \\
\hline$\Gamma^{\prime}$ & Optimum reaction velocity & $\min ^{-1}$ \\
\hline$\varepsilon$ & Effective heating number & - \\
\hline$\Phi_{w}$ & Wind factor & - \\
\hline$\eta_{M}$ & Moisture-dampening coefficient & - \\
\hline$\eta_{S}$ & Mineral dampening coefficient & - \\
\hline$\rho_{b}$ & Fuel bulk density & $\mathrm{kg} \mathrm{m}^{-3}$ \\
\hline$\sigma$ & Surface-area-to-volume ratio & $\mathrm{cm}^{-1}$ \\
\hline$\tau_{c}$ & Critical time for cambial damage & $\min$ \\
\hline$\tau_{l}$ & Residence time of the fire & $\min$ \\
\hline$\omega_{\mathrm{o}}$ & Relative daily litter moisture & - \\
\hline$\xi$ & Propagating flux ratio & - \\
\hline
\end{tabular}


Acknowledgements. This work has been supported by an EU Marie Curie Fellowship (IFBACC, MEIF-CT-2005-010445) to KT. KT received further funding from EU-FP6 funded projects ALARM, ATEAM and COCO. AS is funded through the QUEST Earth System Model (QESM) and QUEST Theme 3 Fire Modelling And Forecasting System (FireMAFS) contracts to the National Centres for Atmospheric Science (NCAS)-Climate, Reading. LD was supported by the EU Hydrogen, Methane, Nitrous Oxide (HYMN) project. The work is a contribution to the EU FIRE-PARADOX project. The gridded satellite lightning data were produced by the NASA LIS/OTD Science Team (Principal Investigator, Hugh Christian, NASA/Marshall Space Flight Center) and are available from the Global Hydrology Resource Center (http://ghrc.msfc.nasa.gov). We thank Ulrich Weber, Hendrik Zwenzner and Carolin Thiel for their assistance in data analysis of the case study regions, and Louis Giglio (NASA) and Ben Poulter (PIK) for help on processing the MODIS data.

The service charges for this open access publication have been covered by the Max Planck Society.

Edited by: A. Arneth

\section{References}

Agee, J. K.: Fire Ecology of Pacific Northwest Forests, Island Press, Washington, DC, 490 pp., 1996.

Albini, F. A.: Estimating Wildfire Behaviour and Effects, Intermountain Forest and Range Experiment Station, Forest Service, US Dept. of Agriculture, Ogden, UtahUSDA Forest Service General Technical Report INT-30, 1976.

Allan, G. E. and Southgate, R. I.: Fire regimes in the spinifex landscapes of Australia, in: Flammable Australia: The fire regimes and Biodiversity of a Continent, edited by: Bradstock, R. A., Williams, J. E., and Gill, M., Cambridge University Press, Cambridge, 145-176, 2002.

Anderson, H. E.: Aids to Determining Fuel Models For Estimating Fire Behavior, USDA Forest Service, Ogden, General Technical Report General Technical Report INT-122, 28, 1982.

Andreae, M. O. and Merlet, P.: Emission of trace gases and aerosols from biomass burning, Global Biogeochem. Cy., 15, 955-966, 2001.

Archibald, S., Roy, D. P., van Wilgen, B. W., and Scholes, R. J.: What limits fire? An examination of drivers of burnt area in Southern Africa, Global Change Biology, 15, 613-630, doi:10.1111/j.1365-2486.2008.01754.x, 2009.

Arora, V. K. and Boer, G. J.: Fire as an interactive component of dynamic vegetation models, J. Geophys. Res., 110, doi:10.1029/2005JG000042, G02008, 2005.

Bachelet, D., Lenihan, J. M., Daly, C., and Neilson, R. P.: Interactions between fire, grazing and climate change at Wind Cave National Park, SD, Ecol. Model., 134, 229-244, 2000.

Bartholome, E. and Belward, A. S.: GLC2000: a new approach to global land cover mapping from Earth observation data, Int. J. Remote Sens., 26, 1959-1977, 2005.

Bergeron, Y., Gauthier, S., Flannigan, M., and Kafka, V.: Fire regimes at the transition between mixedwood and coniferous boreal forest in Northwestern Quebec, Ecology, 85, 1916-1932, 2004.
Brown, D. G.: Predicting vegetation types at treeline using topography and biophysical disturbance variables, J. Veg. Sci., 5, 641656, 1994.

Brown, J. K.: Bulk Densities of Nonuniform Surface Fuels and Their Application to Fire Modeling, Forest Sci., 27, 667-683, 1981.

Byram, G. M.: Combustion of forest fuels, in: Forest Fire: Control and Use, 1 ed., edited by: Davis, K. P., McGraw-Hill Book Company, New York, 61-89, 1959.

Cardoso, M. F., Hurtt, G. C., Moore, B., Nobre, C. A., and Prins, E. M.: Projecting future fire activity in Amazonia, Global Change Biol., 9, 656-669, 2003.

Carmona-Moreno, C., Belward, A., Malingreau, J.-P., Hartley, A., Garcia-Alegre, M., Antonovskiy, M., Buchshtaber, V., and Pivovarov, V.: Characterizing interannual variations in global fire calendar using data from Earth observing satellites, Global Change Biol., 11, 1537-1555, doi:10.1111/j.1365-2486.2005.001003.x, 2005.

CFFBG: Development and structure of the Canadian Forest Fire Behaviour Predictions Systems, Forestry Canada Fire Danger Group, Scientific Sustainable Development Directory, Ottawa, Ont. Inf. Rep. Ont. Inf. Rep. ST-X-3, 1992.

Christian, H. J., Blakeslee, R. J., Boccippio, D. J., Boeck, W. L., Buechler, D. E., Driscoll, K. T., Goodman, S. J., Hall, J. M., Koshak, W. J., Mach, D. M., and Stewart, M. F.: Global frequency and distribution of lightning as observed from space by the Optical Transient Detector, J. Geophys. Res.-Atmos., 108, doi:10.1029/2002JD002347, 4005, 2003.

Cochrane, M. A., Alencar, A., Schulze, M. D., Souza, C. M. J., Nepstad, D. C., Lefebvre, P., and Davidson, E. A.: Positive Feedbacks in the Fire Dynamic of Closed Canopy Tropical Forests, Science, 284, 1832-1835, 1999.

Cochrane, M. A.: Fire science for rainforests, Nature, 421, 913919, 2003.

Cohen, J. D. and Deeming, J. E.: The National Fire-Danger Rating System: basic equations, Pacific Southwest Forest and Range Experiment Station, Berkeley, General Technical Report PSWGTR-82, 23, 1985.

Conard, S. G., Sukhinin, A. I., Stocks, B. J., Cahoon, D. R., Davidenko, E. P., and Ivanova, G. A.: Determining effects of area burned and fire severity on carbon cycling and emissions in Siberia, Climatic Change, 55, 197-211, 2002.

Cramer, W., Bondeau, A., Woodward, F. I., Prentice, I. C., Betts, R. A., Brovkin, V., Cox, P. M., Fisher, V., Foley, J. A., Friend, A. D., Kucharik, C., Lomas, M. R., Ramankutty, N., Sitch, S., Smith, B., White, A., and Young-Molling, C.: Global response of terrestrial ecosystem structure and function to $\mathrm{CO}_{2}$ and climate change: results from six dynamic global vegetation models, Global Change Biol., 7, 357-373, 2001.

De Groot, W., Field, R., Brady, M., Roswintiarti, O., and Mohamad, M.: Development of the Indonesian and Malaysian Fire Danger Rating Systems, Mit. Adapt. Strat. Global Change, 12, 13812386, 2007.

DeFries, R., Hansen, M., Townshend, J. R. G., Janetos, A. C., and Loveland, T. R.: A new global $1 \mathrm{~km}$ data set of percentage tree cover derived from remote sensing, Global Change Biol., 6, 247254, 2000. 
Dickinson, M. B. and Johnson, E. A.: Fire Effects on Trees, in: Forest Fires, Behaviour and ecological effects, edited by: Johnson, E. A. and Miyanishi, K., Academic Press, San Diego, 477-525, 2001.

FAO: The Digitized Soil Map of the World (Release 1.0), Food and Agriculture Organization of the United Nations, Rome, Italy, World Soil Resources Report 67/1, 1991.

FAO: Global Forest Resources Assessment 2005 - Report on fires in the Central Asian Region and adjacent countries, FAO, Rome16, 45, 2006.

Field, R. D., van der Werf, G. R., and Shen, S. S. P.: Human amplification of drought-induced biomass burning in Indonesia since 1960, Nat. Geosci., 2, 185-188, doi:10.1038/ngeo443, 2009.

Flannigan, M. D., Logan, K. A., Amiro, B. D., Skinner, W. R., and Stocks, B. J.: Future area burned in Canada, Climatic Change, 72, 1-16, 2005.

Fosberg, M. A., Cramer, W., Brovkin, V., Fleming, R., Gardner, R., Gill, A. M., Goldammer, J. G., Keane, R., Koehler, P., Lenihan, J., Neilson, R., Sitch, S., Thonicke, K., Venevski, S., Weber, M. G., and Wittenberg, U.: Strategy for a Fire Module in Dynamic Global Vegetation Models, International Journal of Wildland Fire, 9, 79-84, 1999.

French, N. H. F., Kasischke, E. S., and Williams, D. G.: Variability in the emission of carbon-based trace gases from wildfire in the Alaskan boreal forest, J. Geophys. Res.-Atmos., 107, 8151, doi:10.1029/2001JD000480, 2003.

Galanter, M., Levy, H., and Carmichael, G. R.: Impacts of biomass burning on tropospheric $\mathrm{CO}, \mathrm{NO}_{\mathrm{x}}$, and $\mathrm{O}_{3}$, J. Geophys. Res.Atmos., 105, 6633-6653, 2000.

Gerten, D., Schaphoff, S., Haberlandt, U., Lucht, W., and Sitch, S.: Terrestrial vegetation and water balance - hydrological evaluation of a dynamic global vegetation model, J. Hydrol., 286, 249-270, 2004.

Gerten, D., Hoff, H., Bondeau, A., Lucht, W., Smith, P., and Zaehle, S.: Contemporary "green" water flows: Simulations with a dynamic global vegetation and water balance model, Phys. Chem. Earth, 30, 334-338, 2005.

Giglio, L., Csiszar, I., and Justice, C. O.: Global distribution and seasonality of active fires as observed with the Terra and Aqua Moderate Resolution Imaging Spectroradiometer (MODIS) sensors, J. Geophys. Res.-Biogeo., 111, G02016, doi:10.1029/2005JG000142, 2006.

Girardin, M. P., Tardif, J., Flannigan, M. D., Wotton, B. M., and Bergeron, Y.: Trends and periodicities in the Canadian Drought Code and their relationships with atmospheric circulation for the southern Canadian boreal forest, Can. J. Forest Res., 34, 103119, 2004.

Hansen, M., DeFries, R., Townshend, J. R. G., Caroll, M., Dimiceli, C., and Sohlberg, R. A.: Global percentage tree cover at a spatial resolution of 500 meters: First results of the MODIS vegetation continuous fields algorithm, Earth Interact., 7, 1-15, 2003.

Harris, S., Tapper, N., Packham, D., Orlove, B., and Nicholls, N.: The relationship between the monsoonal summer rain and dryseason fire activity of northern Australia, Int. J. Wildland Fire, 17, 674-684, 2008.

Hély, C., Bergeron, Y., and Flannigan, M. D.: Effects of stand composition on fire hazard in mixed-wood Canadian boreal forest, J. Veg. Sci., 11, 813-824, 2000.
Hély, C., Flannigan, M., and Bergeron, Y.: Modeling Tree Mortality Following Wildfire in the Southeastern Canadian Mixed-Wood Boreal Forest, Forest Sci., 49, 566-576, 2003.

Hoelzemann, J. J., Schultz, M. G., Brasseur, G. P., Granier, C., and Simon, M.: Global Wildland Fire Emission Model (GWEM): Evaluating the use of global area burnt satellite data, J. Geophys. Res., 109, D14S04, doi:10.1029/2003JD003666, 2004.

Hoffmann, W. A., Orthen, B., and Do Nascimento, P. K. V.: Comparative fire ecology of tropical savanna and forest trees, Funct. Ecol., 17, 720-726, 2003.

Ito, A., and Penner, J. E.: Global estimates of biomass burning emissions based on satellite imagery for the year 2000, J. Geophys. Res.-Atmos., 109, 10.1029/2003JD004423 D14S05, 2004.

Johnson, E. A.: Fire and vegetation dynamics: Studies from the North American boreal forest, Cambridge studies in ecology, Cambridge University Press, Cambridge, 129 pp., 1992.

Kalnay, E.: The NCEP/NCAR 40-year reanalysis project, B. Am. Meterorol. Soc., 77, 437-470, 1996.

Kasischke, E. S., Hyer, E. J., Novelli, P. C., Bruhwiler, L. P., French, N. H. F., Sukhinin, A. I., Hewson, J. H., and Stocks, B. J.: Influences of boreal fire emissions on Northern Hemisphere atmospheric carbon and carbon monoxide, Global Biogeochem. Cy., 19, GB1012, doi:10.1029/2004GB002300, 2005.

Keane, R. E., Arno, S. F., and Brown, J. K.: Simulating Cumulative Fire Effects in Ponderosa Pine Douglas - Fire Forests, Ecology, 71, 189-203, 1990.

Keane, R. E., Cary, G. J., Davies, I. D., Flannigan, M. D., Gardner, R. H., Lavorel, S., Lenihan, J. M., Li, C., and Rupp, T. S.: A classification of landscape fire succession models: spatial simulations of fire and vegetation dynamics, Ecol. Model., 179, 3-27, 2004.

Klein Goldewijk, K.: Three centuries of global population growth: A spatial referenced population (density) database for 1700 2000, Popul. Environ., 26, 343-367, 2005.

Langner, A. and Siegert, F.: Spatiotemporal fire occurrence in Borneo over a period of 10 years, Global Change Biol., 15, 48-62, doi:10.1111/j.1365-2486.2008.01828.x, 2009.

Latham, D. and Williams, E.: Lightning and Forest Fires, in: Forest Fires. Behavior and Ecological Effects, edited by: Johnson, E. A. and Miyanishi, K., Academic Press, San Diego, 376-418, 2001.

Latham, D. J. and Schlieter, J. A.: Ignition probabilities of Wildland Fuels Based on Simulated Lightning Discharges, Intermountain Research Station, Ogden, UT, Research Paper INT-411, 16, 1989.

Lenihan, J. M. and Neilson, R. P.: Simulating Broad-Scale Fire Severity in a Dynamic Global Vegetation Model, Northwest Sci., 72, 91-103, 1998.

Marlon, J. R., Bartlein, P. J., Carcaillet, C., Gavin, D. G., Harrison, S. P., Higuera, P. E., Joos, F., Power, M. J., and Prentice, I. C.: Climate and human influences on global biomass burning over the past two millennia, Nat. Geosci., 1, 697-702, doi:10.1038/ngeo313, 2008.

Marlon, J. R., Bartlein, P. J., Walsh, M. K., Harrison, S. P., Brown, K. J., Edwards, M. E., Higuera, P. E., Power, M. J., Anderson, R. S., Briles, C., Brunelle, A., Carcaillet, C., Daniels, M., Hu, F. S., Lavoie, M., Long, C., Minckley, T., Richard, P. J. H., Scott, A. C., Shafer, D. S., Tinner, W., Umbanhowar, C. E., and Whitlock, C.: Wildfire responses to abrupt climate change in North America, P. Natl. Acad. Sci., 106, 2519-2524, 
doi:10.1073/pnas.0808212106, 2009.

McGuire, A. D., Sitch, S., and Clein, J. S.: Carbon balance of the terrestrial biosphere in the twentieth century: analyses of $\mathrm{CO}_{2}$, climate and land use effects with four process-based ecosystem models., Global Biogeochem. Cy., 15, 183-206, 2001.

Merida, J.-C.: Descripción de los modelos combustibles usados en la prediccion del comportamiento del fuego, Àrea de Defensa Contra Incendios Forestales, Ministerio de Medio Ambiente España, Madrid, 1999.

Mermoz, M., Kitzberger, T., and Veblen, T. T.: Landscape influences on occurrence and spread of wildfires in Patagonian forests and shrublands, Ecology, 86, 2705-2715, 2005.

Miller, C. and Urban, D. L.: Interactions between forest heterogeneity and surface fire regimes in the southern Sierra Nevada, Can. J. Forest Res., 29, 202-212, 1999.

Moreno, J. M., Vázquez, A., and Vélez, R.: Recent History of Forest Fires in Spain, in: Large Forest Fires, edited by: Moreno, J. M., Backhuys Publishers, Leiden, 159-185, 1998.

Myneni, R. B., Dong, J., Tucker, C. J., Kaufmann, R. K., Kauppi, P. E., Liski, J., Zhou, L., Alexeyev, V., and Hughes, M. K.: A large carbon sink in the woody biomass of northern forests, P. Natl. Acad. Sci. USA, 98, 14784-14789, 2001.

Nesterov, V. G.: Gorimost' lesa i metody eio opredelenia, Goslesbumaga, Moscow, 1949.

$\mathrm{Ni}$, J.: Estimating net primary productivity of grasslands from field biomass measurements in temperate northern China, Plant Ecology, 174, 217-234, 2004.

Olson, D. M., Dinerstein, E., Wikramanayake, E. D., Burgess, N. D., Powell, G. V. N., Underwood, E. C., D’Amico, J. A., Itoua, I., Strand, H. E., Morrison, J. C., Loucks, C. J., Allnutt, T. F., Ricketts, T. H., Kura, Y., Lamoreux, J. F., Wettengel, W. W., Hedao, P., and Kassem, K. R.: Terrestrial Ecoregions of the World: A New Map of Life on Earth, Bioscience, 51, 933-938, 2001.

Pausas, J. G., Bradstock, R. A., Keith, D. A., and Keeley, J. E.: Plant functional traits in relation to fire in crown-fire ecosystems, Ecology, 85, 1085-1100, 2004.

Peterson, D. L. and Ryan, K. C.: Modeling Postfire Conifer Mortality for Long-range Planning, Environ. Manage., 10, 797-808, 1986.

Peylin, P., Bousquet, P., Le Quere, C., Sitch, S., Friedlingstein, P., McKinley, G., Gruber, N., Rayner, P., and Ciais, P.: Multiple constraints on regional $\mathrm{CO}_{2}$ flux variations over land and oceans, Global Biogeochem. Cy., 19, GB1011, doi:10.1029/2003GB002214, 2005.

Power, M. J., Marlon, J., Ortiz, N., Bartlein, P. J., Harrison, S. P., Mayle, F. E., Ballouche, A., Bradshaw, R. H. W., Carcaillet, C., Cordova, C., Mooney, S., Moreno, P. I., Prentice, I. C., Thonicke, K., Tinner, W., Whitlock, C., Zhang, Y., Zhao, Y., Ali, A. A., Anderson, R. S., Beer, R., Behling, H., Briles, C., Brown, K. J., Brunelle, A., Bush, M., Camill, P., Chu, G. Q., Clark, J., Colombaroli, D., Connor, S., Daniau, A. L., Daniels, M., Dodson, J., Doughty, E., Edwards, M. E., Finsinger, W., Foster, D., Frechette, J., Gaillard, M. J., Gavin, D. G., Gobet, E., Haberle, S., Hallett, D. J., Higuera, P., Hope, G., Horn, S., Inoue, J., Kaltenrieder, P., Kennedy, L., Kong, Z. C., Larsen, C., Long, C. J., Lynch, J., Lynch, E. A., McGlone, M., Meeks, S., Mensing, S., Meyer, G., Minckley, T., Mohr, J., Nelson, D. M., New, J., Newnham, R., Noti, R., Oswald, W., Pierce, J., Richard, P. J. H., Rowe, C., Goni, M. F. S., Shuman, B. N., Takahara, H.,
Toney, J., Turney, C., Urrego-Sanchez, D. H., Umbanhowar, C., Vandergoes, M., Vanniere, B., Vescovi, E., Walsh, M., Wang, X., Williams, N., Wilmshurst, J., and Zhang, J. H.: Changes in fire regimes since the Last Glacial Maximum: an assessment based on a global synthesis and analysis of charcoal data, Clim. Dynam., 30, 887-907, doi:10.1007/s00382-007-0334-x, 2008.

Pyne, S. J., Andrews, P. L., and Laven, R. D.: Introduction to wildland fire, 2 edition, Wiley, New York, 769 pp., 1996.

Randerson, J. T., van der Werf, G. R., Collatz, G. J., Giglio, L., Still, C. J., Kasibhatla, P., Miller, J. B., White, J. W. C., DeFries, R. S., and Kasischke, E. S.: Fire emissions from C-3 and C-4 vegetation and their influence on interannual variability of atmospheric $\mathrm{CO} 2$ and delta( $\left(\mathrm{CO}_{2}\right)-\mathrm{C}-13$, Global Biogeochem. Cy., 19, GB2019, doi:10.1029/2004GB002366, 2005.

Reinhardt, E. D., Keane, R. E., and Brown, J. K.: First Order Fire Effects Model: FOFEM 4.0, User's Guide, USDA Forest Service Intermountain Research Station, OgdenResearch Paper INTGTR-344, 1997.

Rigolot, E.: Predicting postfire mortality of Pinus halepensis Mill. and Pinus pinea L, Plant Ecol., 171, 139-151, 2004.

Rothermel, R. C.: A Mathematical Model for Predicting Fire Spread in Wildland Fuels, Intermountain Forest and Range Experiment Station, Forest Service, US Dept. of Agriculture, Ogden, UtahUSDA Forest Service General Technical Report INT$115,1972$.

Running, S. W., Ramakrishna, R. N., and Hungerford, R. D.: Extrapolation of synoptic meteorological data in mountainous terrain and its use for simulating forest evapotranspiration and photosynthesis, Can. J. Forest Res., 17, 472-483, 1987.

Schimmel, J. and Granström, A.: Fuel Succession and fire behaviour in the Swedish boreal forest, Can. J. Forest Res., 27, 1207-1216, 1997.

Schultz, M. G., Heil, A., Hoelzemann, J. J., Spessa, A., Thonicke, K., Goldammer, J. G., Held, A. C., Pereira, J. M. C., and van het Bolscher, M.: Global wildland fire emissions from 1960 to 2000, Global Biogeochem. Cy., 22, GB2002, doi:10.1029/2007GB003031, 2008.

Scott, J. H. and Reinhardt, E. D.: Assessing Crown Fire Potential by Linking Models of Surface and Crown Fire Behavior, US Department of Agriculture, Forest Service, Rocky Mountain Research Station, Fort Collins, Research Paper RMRS-RP-29, 59, 2001.

Seiler, W. and Crutzen, P. J.: Estimates of gross and net fluxes of carbon between the biosphere and the atmosphere from biomass burning, Climatic Change, 2, 207-247, 1980.

Sitch, S., Smith, B., Prentice, I. C., Arneth, A., Bondeau, A., Cramer, W., Kaplan, J. O., Levis, S., Lucht, W., Sykes, M. T., Thonicke, K., and Venevsky, S.: Evaluation of ecosystem dynamics, plant geography and terrestrial carbon cycling in the LPJ Dynamic Global Vegetation Model, Global Change Biol., 9, 161-185, doi:10.1046/j.1365-2486.2003.00569.x, 2003.

Stephens, S. L. and Finney, M. A.: Prescribed fire mortality of Sierra Nevada mixed conifer tree species: effects of crown damage and forest floor combustion, Forest Ecol. Manage., 162, 261271, 2002.

Stephens, S. L. and Moghaddas, J. J.: Experimental fuel treatment impacts on forest structure, potential fire behavior, and predicted tree mortality in a California mixed conifer forest, Forest Ecol. Manage., 215, 21-36, 2005. 
Stocks, B. J., Mason, J. A., Todd, J. B., Bosch, E. M., Wotton, B. M., Amiro, B. D., Flannigan, M. D., Hirsch, K. G., Logan, K. A., Martell, D. L., and Skinner, W. R.: Large forest fires in Canada, 1959-1997, J. Geophys. Res., 107, 8149, doi:10.1029/2001JD000484, 2003.

Stocks, B. J., Alexander, M. E., Wotton, B. M., Stefner, C. N., Flannigan, M. D., Taylor, S. W., Lavoie, N., Mason, J. A., Hartley, G. R., Maffey, M. E., Dalrymple, G. N., Blake, T. W., Cruz, M. G., and Lanoville, R. A.: Crown fire behaviour in a northern jack pine-black spruce forest, Can. J. Forest Res., 34, 1548-1560, 2004.

Sukhinin, A. I., French, N. H. F., Kasischke, E. S., Hewson, J. H., Soja, A. J., Csiszar, I. A., Hyer, E. J., Loboda, T., Conrad, S. G., Romasko, V. I., Pavlichenko, E. A., Miskiv, S. I., and Slinkina, O. A.: AVHRR-based mapping of fires in Russia: New products for fire management and carbon cycle studies, Remote Sens. Environ., 93, 546-564, 2004.

Telitsyn: Lesnye pozhary, ich preduprezhdenie i bor'ba s nimi v Khabarovskom krae, DALNIILKH, Khabarovsk, 94 pp., 1988.

Telitsyn, H. P.: A Mathematical Model of Spread of High-Intensity Forest Fires, in: Fire in Ecosystems of Boreal Eurasia, edited by: Goldammer, J. G. and Furyaev, V. V., Forestry Sciences, Kluwer Academic Publishers, Dordrecht - Boston - London, 139-150, 1996.

Thonicke, K., Venevsky, S., Sitch, S., and Cramer, W.: The role of fire disturbance for global vegetation dynamics: coupling fire into a Dynamic Global Vegetation Model, Global Ecol. Biogeogr., 10, 661-678, doi:10.1046/j.1466-822X.2001.00175.x, 2001.

Uhl, C. and Kauffman, J. B.: Deforestation, Fire susceptibility, and potential tree responses to fire in the Eastern Amazon, Ecology, 71, 437-449, 1990. van der Werf, G. R., Randerson, J. T., Collatz, G. J., and Giglio, L.: Carbon emissions from fires in tropical and subtropical ecosystems, Global Change Biol., 9, 547-562, 2003.

van der Werf, G. R., Randerson, J. T., Collatz, G. J., Giglio, L., Kasibhatla, P. S., Arellano, A. F., Olsen, S. C., and Kasischke, E. S.: Continental-scale partitioning of fire emissions during the 1997 to $2001 \mathrm{El}$ Nino/La Nina period, Science, 303, 73-76, 2004.

van der Werf, G. R., Randerson, J. T., Giglio, L., Collatz, G. J., Kasibhatla, P. S., and Arellano Jr., A. F.: Interannual variability in global biomass burning emissions from 1997 to 2004, Atmos. Chem. Phys., 6, 3423-3441, doi:10.5194/acp-6-3423-2006, 2006.

Van Wagner, C. E.: Conditions for the start and spread of crown fire, Can. J. Forest Res., 7, 23-34, 1977.

Venevsky, S., Thonicke, K., Sitch, S., and Cramer, W.: Simulating fire regimes in human-dominated ecosystems: Iberian Peninsula case study, Global Change Biol., 8, 984-998, doi:10.1046/j.1365-2486.2002.00528.x, 2002.

Verseghy, D., McFarlane, N. A., and Lazare, M.: CLASS - A Canadian land surface scheme for GCMs: II. Vegetation model and coupled runs, Int. J. Climatol., 13, 347-370, 1993.

Weber, U.: Analysis of inter-annual fire activity and emissions from biomass burning in Borneo in relation to ENSO and land use change, 1997-2003, Geography, Friedrich-Schiller-Universität Jena, Jena, Germany, 2006.

Whelan, R. J.: The Ecology of Fire, Cambridge studies in ecology, Cambridge University Press, Cambridge, 346 pp., 1995.

Williams, R. J., Gill, A. M., and Moore, P. H. R.: Seasonal Changes in Fire Behaviour in a Tropical Savanna in Northern Australia, Int. J. Wildland Fire, 8, 227-239, 1998.

Wilson Jr., R. A.: A reexamination of fire spread in free burning porous fuel beds, Ogden, UTINT-289, 28, 1982.

Zobler, L.: A World Soil File for Global Climate Modeling, Goddard Institute for Space Studies, New York, 1986. 